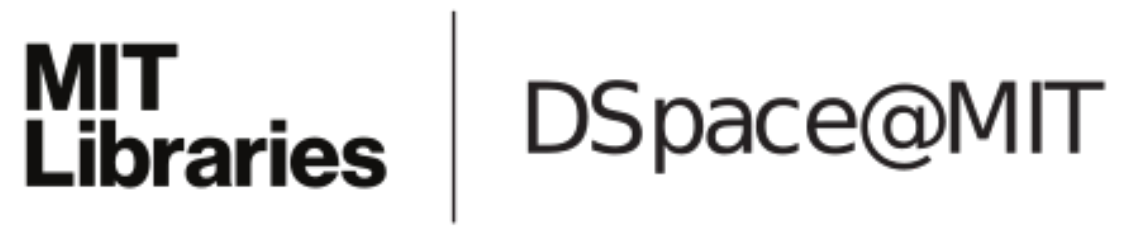

\author{
MIT Open Access Articles
}

Naphthazarin-Polycyclic Conjugated Hydrocarbons and Iptycenes

The MIT Faculty has made this article openly available. Please share how this access benefits you. Your story matters.

Citation: Dengiz, Cagatay, et al. "Naphthazarin-Polycyclic Conjugated Hydrocarbons and Iptycenes." The Journal of Organic Chemistry 82, 14 (July 2017): 7470-7480 @ 2017 American Chemical Society

As Published: http://dx.doi.org/10.1021/acs.joc.7b01170

Publisher: American Chemical Society (ACS)

Persistent URL: http://hdl.handle.net/1721.1/116849

Version: Author's final manuscript: final author's manuscript post peer review, without publisher's formatting or copy editing

Terms of Use: Article is made available in accordance with the publisher's policy and may be subject to US copyright law. Please refer to the publisher's site for terms of use. 


\title{
Naphthazarin-Polycyclic Conjugated Hydrocarbons and Iptycenes
}

\author{
Cagatay Dengiz ${ }^{\S}$, Sarah P. Luppino ${ }^{\S}$, Gregory D. Gutierrez, and Timothy M. Swager* \\ Department of Chemistry, Massachusetts Institute of Technology, Cambridge, MA \\ 02139, United States
}

\begin{abstract}
The synthesis of a set of naphthazarin-containing polycyclic conjugated hydrocarbons is described herein. Sequential Diels-Alder reactions on a tautomerized naphthazarin core were employed to access the final conjugated systems. Complete conjugation across the backbone can be achieved through complexation with $\mathrm{BF}_{2}$, as observed by ${ }^{1} \mathrm{H}$ NMR analysis and UV/vis spectroscopy. Precise synthetic control over the degree of oxidation of naphthazarin quinone Diels-Alder adduct $\mathbf{1 0}$ is additionally demonstrated, and enables us to direct its subsequent reactivity. Finally, this work serves to demonstrate the potential for naphthazarin as a building block in the synthesis of novel organic electronic materials.
\end{abstract}

Keywords: naphthazarin / Diels-Alder reactions / phenylene-containing oligoacenes / $\mathrm{BF}_{2}$-complex / polycyclic conjugated hydrocarbons / iptycenes 


\section{INTRODUCTION}

Polycyclic conjugated hydrocarbons are organic small molecules of interest as active materials in electronic and optoelectronic devices. Acenes, such as pentacene and triisopropylsilyl-pentacene (TIPS-pentacene), are among the top performers in organic field effect transistors (OFETs), ${ }^{1,2}$ and while they have achieved significant milestones, ${ }^{3}$ considerable efforts remain focused on the design and synthesis of new classes of compounds to achieve a desired boost in performance and material stability.

To this end, synthetic chemists have explored structural modifications to the acene core to achieve improved stability, processibility, and electronic properties. Strategies include appending bulky or electron-withdrawing substituents, ${ }^{1,4}$ or including heteroatoms into the core acene unit, such as in the synthesis of anthradithiophenes or azaacenes. ${ }^{1,5-13}$ Other efforts explore a redesign of the bonding architecture of the core molecule, such as through the incorporation of formally antiaromatic cyclobutadiene units, present in $[\mathrm{N}]$ phenylenes and phenylenecontaining oligoacenes (POAs). ${ }^{14-19}$ Alternation of cyclobutadiene units with either benzene $([\mathrm{N}]$ phenylenes) or acene units (POAs) results in localized conjugation along the molecular backbone, which can improve chromophore stability. ${ }^{15,16}$

Key synthetic approaches to building acene or acene-like small molecules include sequential Diels-Alder reactions, ${ }^{16,20,21}$ cross-coupling methods, ${ }^{6,22}$ or the $[2+2+2]$ methodology used by Vollhardt and coworkers to synthesize extended $[\mathrm{N}]$ phenylenes. ${ }^{15}$

In this study, we capitalize on the ability of naphthazarin (1,4-dihydroxy-5,8naphthaquinone $)^{23-25}$ to act as a bifunctional Diels-Alder reagent to access new iptycene and POA molecules in a convergent manner. Examples of target structures are presented in Figure 1. Naphthazarin has the ability to react twice as a dienophile, ${ }^{26}$ 
which can be achieved via oxidation and tautomerization of the initial Diels-Alder adduct to unmask a second dienophile equivalent on the opposite side of the naphthazarin core. This makes it an appealing building block to convergently synthesize multi-ring systems. Historically, naphthazarins have been utilized predominantly in the construction of anthracyclinones, ${ }^{23-27}$ and in this study we intend to demonstrate its further potential as a useful building block in the synthesis of organic electronic materials.

We also demonstrate that the naphthazarin-derived Diels-Alder adducts presented herein can coordinate to two $\mathrm{BF}_{2}$ groups to form conjugated electrondeficient complexes. ${ }^{28,29}$ These types of materials may prove useful as electrontransporting materials and n-type semiconductors. ${ }^{28,29}$ To this end, we report the synthesis and spectroscopic properties of a set of triptycene, pentiptycene, and POA naphthazarin-based structures (Figure 1), as well as a proof-of-concept demonstration of their complexation with $\mathrm{BF}_{3}-\mathrm{OEt}_{2}$.

Figure 1. Three of the naphthazarin-containing target molecules synthesized in this study.

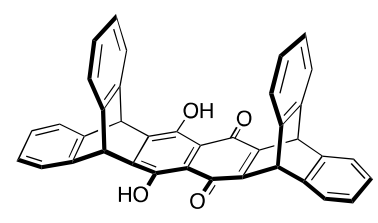

1a

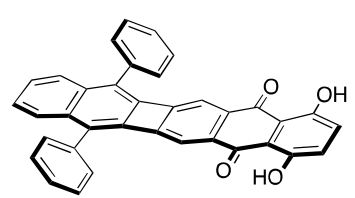

2a

\section{RESULTS AND DISCUSSION}

Synthesis of naphthazarin triptycene derivatives $7 \mathbf{a}-\mathbf{d}$. Triptycene compounds $7 \mathbf{a}-$ d were accessed through an initial [4+2] Diels-Alder cycloaddition reaction of 
naphthazarin (5) with a corresponding anthracene (4a-d) to furnish monocycloadducts $\mathbf{6 a}-\mathbf{d}$, followed by oxidation to the target triptycene intermediates $7 \mathbf{a}-\mathbf{d}$ (Scheme 1).

Scheme 1. Synthesis of naphthazarin triptycenes $7 \mathbf{a}-\mathbf{d}$ and pentiptycenes $\mathbf{1 a}-\mathbf{d}$.
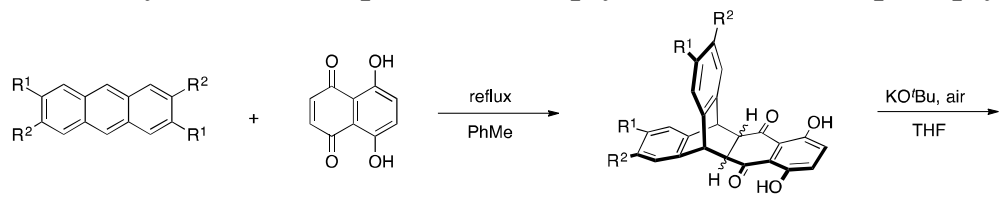

4a $R^{1}=R^{2}=H$ $4 b R^{1}=R^{2}=M e$
$4 c R^{1}=t_{B u ~} R^{2}=H$ 4c $R^{1}=\mathrm{TB} \mathrm{R}^{2}=\mathrm{H}$
4d $R^{1}, \mathrm{R}^{2}=\mathrm{Me}_{4} \mathrm{Cy}=$

5

$6 \mathbf{a} R^{1}=R^{2}=H(62 \%$ yield $)$ $6 b \mathrm{R}^{1}=\mathrm{R}^{2}=\mathrm{Me}(53 \%$ yield $)$ $6 c \mathrm{R}^{1}=\mathrm{BB}^{2}=\mathrm{H}(20 \%$ yield $)$
$6 \mathrm{~d} \mathrm{R} \mathrm{R}^{1}, \mathrm{R}^{2}=\mathrm{Me}_{4} \mathrm{Cy}(80 \%$ yield $)$

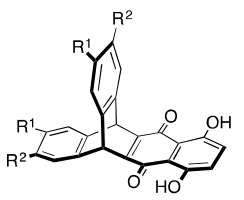

$7 a R^{1}=R^{2}=H(98 \%$ yield $)$ $7 b \mathrm{R}^{1}=\mathrm{R}^{2}=\mathrm{Me}(76 \%$ yield $)$ $7 c R^{1}={ }^{\mathrm{B} u} \mathrm{R}^{2}=\mathrm{H}$ (99\% yield) $7 \mathrm{~d} \mathrm{R}{ }^{1}, \mathrm{R}^{2}=\mathrm{Me}_{4} \mathrm{Cy}$ ( $85 \%$ yield)<smiles>CC1(C)CCCC1</smiles>
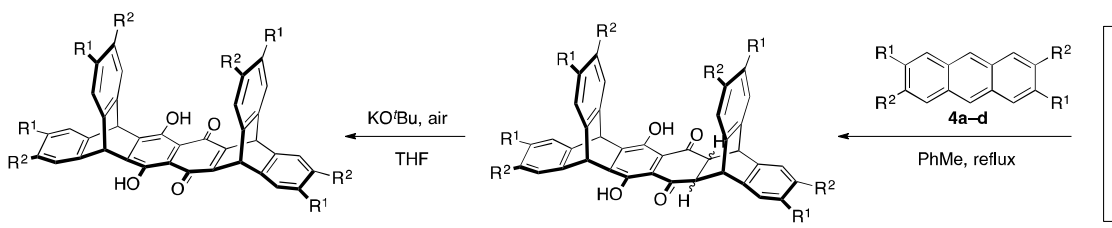

1a $R^{1}=R^{2}=H(69 \%$ yield $)$ 1b $R^{1}=R^{2}=M e$ ( $54 \%$ yield)

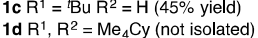

$8 a R^{1}=R^{2}=H(41 \%$ yield $)$ $8 b R^{1}=R^{2}=\mathrm{Me}(48 \%$ yield $)$ 8c $R^{1}=\mathrm{BBu}^{2}=\mathrm{H}(31 \%$ yield $)$

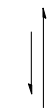

Formation of cycloadducts $\mathbf{6 a}-\mathbf{d}$ occurred in moderate to good yields (20$80 \%$ ). Oxidation of $\mathbf{6 a}-\mathbf{d}$ in the presence of air and excess of $\mathrm{KO}^{t} \mathrm{Bu}$ produced naphthazarin triptycenes $\mathbf{7 a - d}$ in nearly quantitative yields. Reactivity of the anthracene precursors with naphthazarin varies, and we observe anthracene $4 \mathbf{d}$ reacting in the highest yield, likely due to its more electron-rich character relative to the other selected anthracenes.

Single crystals of $\mathbf{6 b}, 7 \mathbf{a}$, and $\mathbf{8 a}$ suitable for X-ray crystallography were obtained by slow evaporation from $\mathrm{CH}_{2} \mathrm{Cl}_{2} / n$-hexane at $25{ }^{\circ} \mathrm{C}$ (Figures 2 and $\mathrm{S} 1-3$, Supporting Information). Although DFT calculations support the tetrasubstituted quinone tautomer $7 \mathbf{a}$ as the more thermodynamically stable isomer, ${ }^{23}$ the crystal structure of 7a was elucidated as tautomer 7a-T. Calculations at the B3LYP/6-31G(d) level showed that the energy difference between structures $7 \mathbf{a}$ and $7 \mathbf{a}-\mathbf{T}$ is 1.05 
$\mathrm{kcal} / \mathrm{mol}$. (For further details on the computational investigations, see the Supporting Information.)

Figure 2. Three X-ray crystal structures of iptycenes $\mathbf{6 b}, 7 \mathbf{a}$, and $8 \mathbf{a}$.

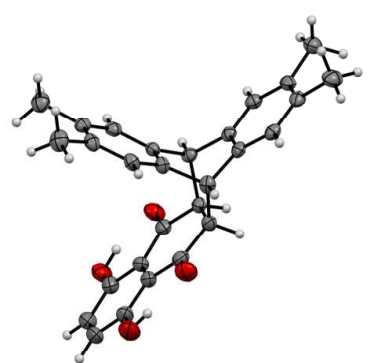

6b

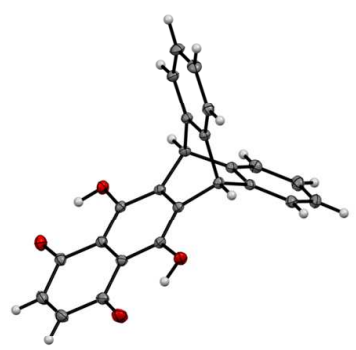

$7 \mathbf{a}$

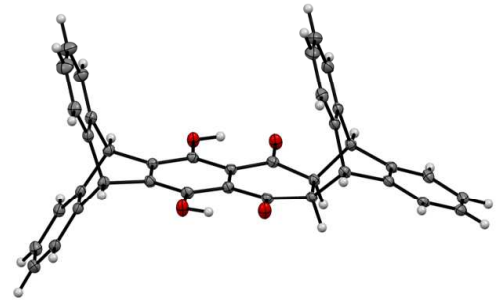

$8 \mathbf{a}$

Synthesis of naphthazarin pentiptycene compounds 1a-d. Naphthazarin-based cycloadducts are known to tautomerize to expose the quinone-based dienophile (7-T), which can undergo a second cycloaddition reaction with a diene. ${ }^{26}$ Upon heating, we observed a second equivalent of $\mathbf{4 a -}-\mathbf{d}$ to undergo a [4+2] cycloaddition with $\mathbf{7 a -} \mathbf{\mathbf { d }}$ to yield double-cyloadducts $\mathbf{8 a - d}$ in $31-61 \%$ yields (Scheme 1).

Similar to the conversion observed from $\mathbf{6 a}-\mathbf{d}$ to $7 \mathbf{a}-\mathbf{d}$, we found that $\mathrm{KO}^{t} \mathrm{Bu}$ enolized cycloadducts $\mathbf{8 a}-\mathbf{c}$ and, in the presence of air, cleanly transformed them into 1a-c in excellent yield. This method of oxidation is very mild, and enables us to access a portfolio of functionalized naphthazarin pentiptycenes ${ }^{30}$ with varying degrees of internal free volume. ${ }^{31}$ Isolation of pentiptycene 1d, however, was not possible. Although we observed characteristic changes in color that signified conversion of $\mathbf{8 d}$ to $\mathbf{1 d}$ (from yellow to dark blue upon addition of $\mathrm{KO}^{t} \mathrm{Bu}$, then to dark red after workup), our attempts to isolate 1d were unsuccessful as a result of the limited solubility and unexpected decomposition of the product. (See Figure S46 for the UV/vis spectrum of the final reaction mixture.)

Synthesis of naphthazarin phenylene-containing-oligoacene compounds 2a-b and 3. We next hypothesized that the Diels-Alder reactivity of the naphthazarin core 
could be extended to a synthetic approach to access novel POAs. ${ }^{16,19}$ Naphthazarin presents an opportunity to incorporate an electron-deficient acene unit into the POA backbone, in particular when complexed with $\mathrm{BF}_{2}$. The naphthazarin motif also provides functional handles for further synthetic manipulation or complexation to metals $^{32,33}$ and boron moieties. ${ }^{28,29}$

To synthesize naphthazarin-derived POAs, we utilized diene 9, which can be accessed in two steps according to literature procedures. ${ }^{16,19,34-39}$ Diene 9 was reacted with naphthazarin (5) to furnish mono-adduct $\mathbf{1 0}$ in $49 \%$ yield (Scheme 2). Interestingly, X-ray crystallographic analysis of compound $\mathbf{1 0}$ shows a trans arrangement of the hydrogen atoms located at the adduct site (Figure S4 in the SI). This is in stark contrast to the expected stereochemistry of Diels-Alder cycloaddition products, as the exo and/or endo product is often observed, and the resultant placement of hydrogen atoms in space depends on this product ratio. ${ }^{40}$ The trans relationship in the crystal structure of $\mathbf{1 0}$ could signify that the operative mechanism of reaction is, in fact, step-wise instead of a true concerted cycloaddition. Alternatively, the trans relationship may be due to epimerization resulting from enolization at the $\alpha$-carbon that occurs following a conventional cis [4+2] cycloaddition. An explanation is that the hydrogen-bonding between the hydroxyl groups and the ketones of the naphthazarin core increases the likelihood of enolization at the $\alpha$-carbons, and, for sterically-induced reasons, the hydrogen atoms end up trans to one another. While we observe a trans relationship for compound $\mathbf{1 0}$ by X-ray analysis, we detect the presence of three isomers by NMR (Figure S84 in the SI), leading us to conclude that the trans product is likely present alongside the endo and exo adducts.

Scheme 2. Targeted synthesis of naphthazarin POA mono-adducts $\mathbf{2 a}-\mathbf{b}$. 


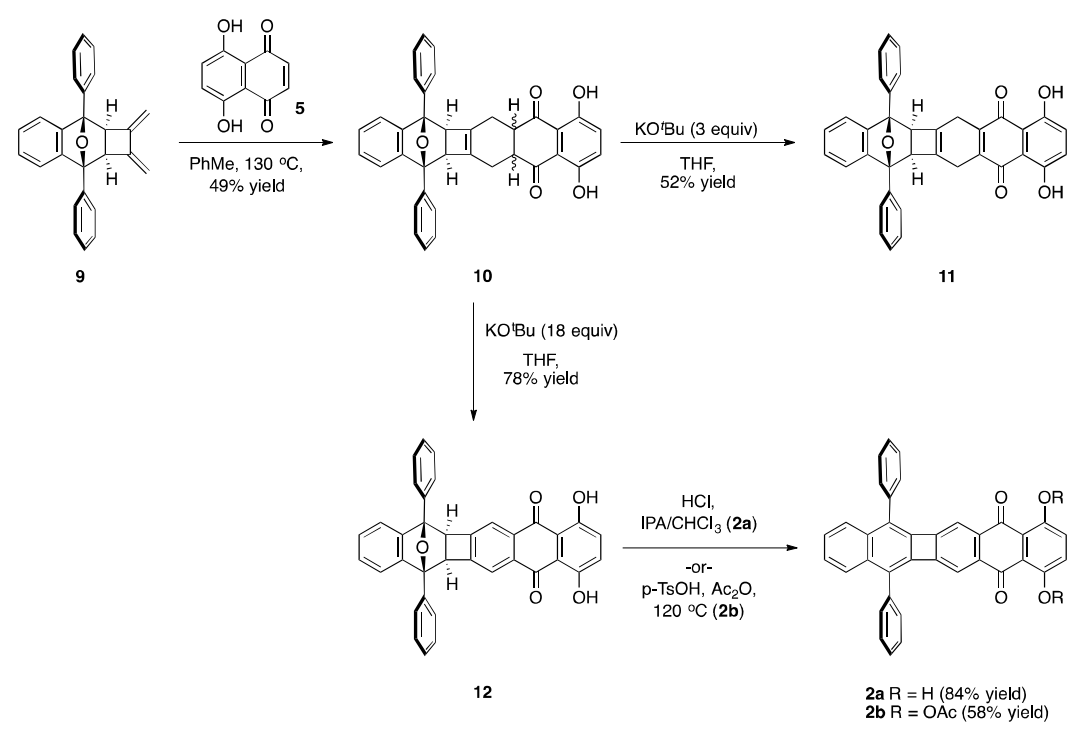

With 10 in hand, we next unmasked dienophile 11-T to enable further DielsAlder reactivity (Scheme 3), and found an interesting dependence on the equivalents of $\mathrm{KO}^{t} \mathrm{Bu}$ used. By adjusting the amount of $\mathrm{KO}^{t} \mathrm{Bu}$ and reaction time, we were able to effectively tune the level of oxidation to produce either partially-oxidized product $\mathbf{1 1}$ or fully-oxidized product 12 (Scheme 2 ). ${ }^{26}$ This capability is significant, as we found that only partially-oxidized $\mathbf{1 1}$ is able to further tautomerize in situ to produce 11-T, which brandishes an external-facing dienophile. Fully-oxidized 12 contains an additional aromatic ring that stabilizes and "locks" the internal 9,10-quinone in place. Here, we found that when mono-adduct $\mathbf{1 0}$ was reacted with only three equivalents of $\mathrm{KO}^{t} \mathrm{Bu}$ for a short period of time (five minutes), we were able to achieve the partially oxidized product $\mathbf{1 1}$ in $52 \%$ yield. When reacted in significant excess and for extended periods of time, the fully oxidized product $\mathbf{1 2}$ became the major or sole product (18 equiv., 78\% yield). X-ray crystal structures of 10-12 are shown in Figures S4-S6 in the SI.

Fully-oxidized $\mathbf{1 2}$ can be converted to target compound $\mathbf{2 a}$ in $84 \%$ yield through hydrolysis of the bridging oxygen when exposed to an acidic solution of hydrochloric acid in chloroform and isopropyl alcohol. ${ }^{41}$ Poor solubility of $\mathbf{2 a}$ 
prevented acquisition of a ${ }^{13} \mathrm{C}$ NMR spectrum. An alternative target was found in $\mathbf{2} \mathbf{b}$, which proved more soluble than $\mathbf{2 a}$, and can be obtained through conversion from $\mathbf{1 2}$ (58\% yield) or from $2 \mathbf{a}\left(49 \%\right.$ yield) using $p$ - $\mathrm{TsOH} / \mathrm{Ac}_{2} \mathrm{O}$.

Scheme 3. Targeted synthesis of POA double-adduct 14.
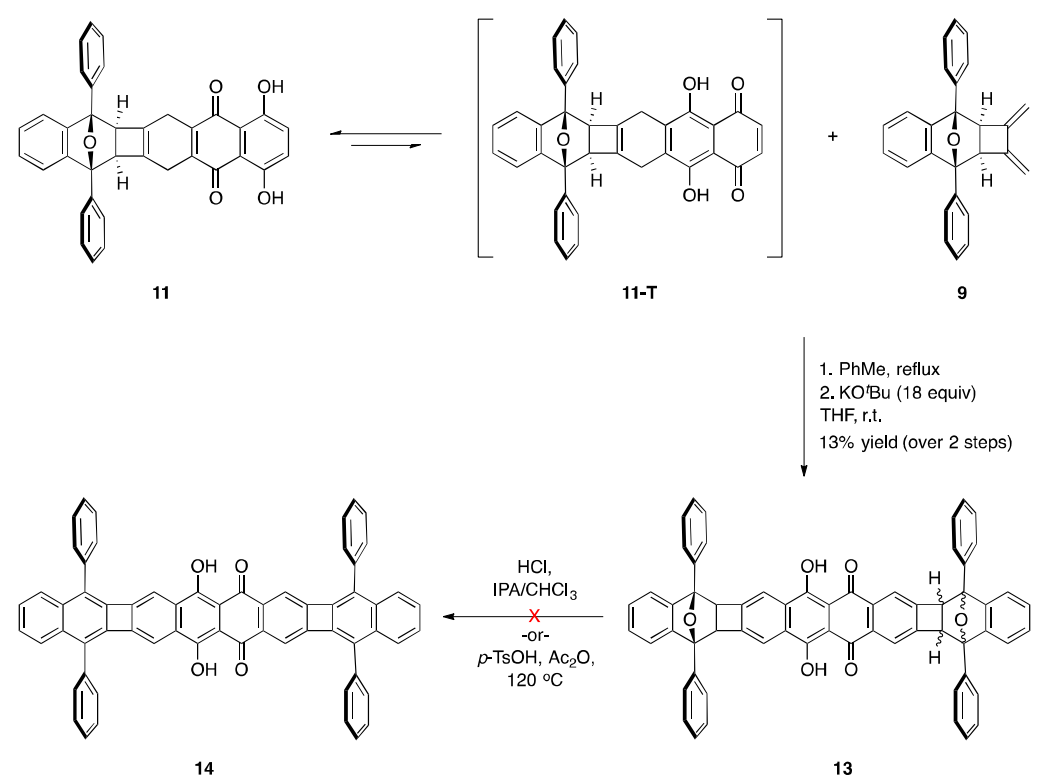

13

We next induced tautomerization of partially-oxidized 11, and reacted the in situ-generated 11-T dienophile with diene 9 for a second cycloaddition reaction. Overall, Diels-Alder reaction of 11-T with diene 9 and subsequent oxidation with $\mathrm{KO}^{t} \mathrm{Bu}$ in the presence of air yielded $\mathbf{1 3}$ in $13 \%$ yield. Unfortunately, multiple attempts to convert $\mathbf{1 3}$ to the final symmetrical POA double-adduct $\mathbf{1 4}$ failed. The challenges we faced in isolating $\mathbf{1 4}$ were likely due to poor solubility, as was similarly encountered with pentiptycene 1d and POA mono-adduct 2a. We did observe consumption of $\mathbf{1 3}$ upon exposure to acid and were able to detect $\mathbf{1 4}$ by MALDI-TOF mass spectrometry (see Figure S112). However, the reaction largely produced a substantial amount of insoluble material that we were unable to isolate for full characterization. 
To circumvent these problems, we redesigned our synthetic plan and instead targeted compound 3 (Scheme 4). We hypothesized that the non-planar triptycene end-group of $\mathbf{3}$ would eliminate the aforementioned solubility and aggregation issues. $^{31}$ We attempted to react the in situ generated 11-T dienophile with one equivalent of anthracene $\mathbf{4 a}$, but were only able to observe trace amounts of product by TLC.

Scheme 4. Targeted synthesis of iptycene-POA 3.

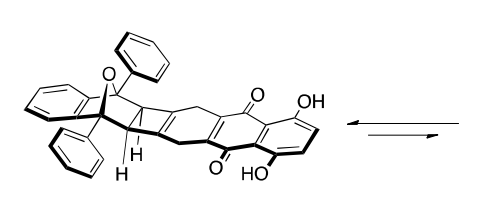

11

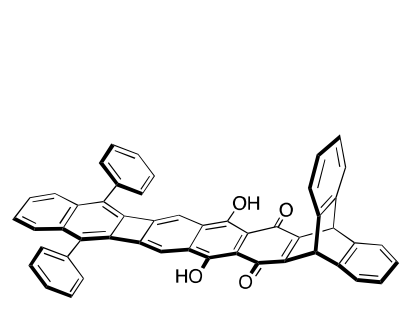

3

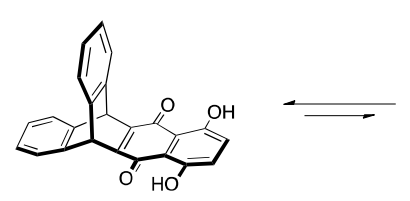

$7 a$

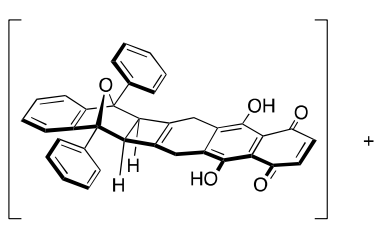

11-T
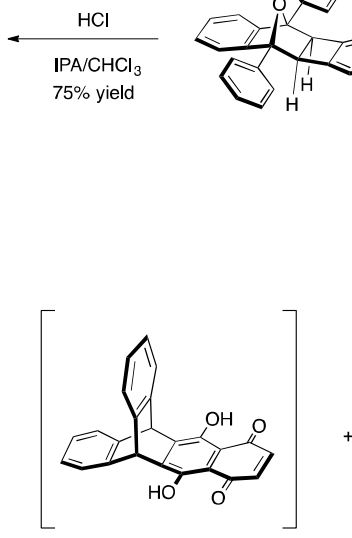

7a-T

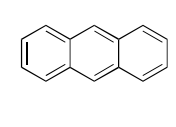

$4 a$

1. PhMe, reflux 2. KO'Bu (18 equiv) THF, r.t.

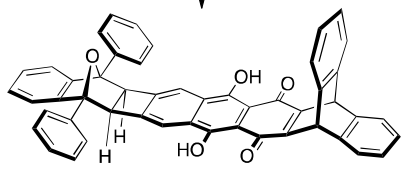

15

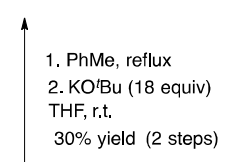

$30 \%$ yield (2 steps)

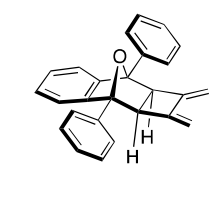

9

Due to the insufficient reactivity of 11-T, we sought to access target compound $\mathbf{3}$ by reversing our synthetic strategy. To this end, we were able to successfully react $7 \mathbf{a}$ with diene 9 to yield double-adduct POA-iptycene $\mathbf{1 5}$ in 30\% yield over two steps. The final product 3 could be accessed under acidic conditions and collected in $75 \%$ yield as a dark-orange product. This compound proved reasonably soluble in 1,1,2,2tetrachloroethane and could be characterized, but was exemplary of the solubility challenges faced in trying to access the symmetrical double POA adduct. 


\section{Spectroscopic Properties of mono- and double-adducts}

The UV/vis spectra of four selected naphthazarin derivatives 1a, 2a, 3, and 7a are shown in Figure 3a (See Figures S12-22 in the SI for the UV/vis spectra of all compounds). The UV/vis spectra of $\mathbf{1 a}, \mathbf{2 a}, \mathbf{3}$, and $\mathbf{7 a}$ are characteristic of naphthazarins, showing vibronically coupled bands with significant fine structures at lower energy. The deep red-colored compound 7a exhibits a fine-structure absorption band at $\lambda_{\max }=568 \mathrm{~nm}\left(2.18 \mathrm{eV}, \varepsilon=4800 \mathrm{M}^{-1} \mathrm{~cm}^{-1}\right)$. The additional triptycene unit in 1a caused a bathochromic shift of $8 \mathrm{~nm}\left[\lambda_{\max }=576 \mathrm{~nm}\left(2.15 \mathrm{eV}, \varepsilon=6900 \mathrm{M}^{-1} \mathrm{~cm}^{-1}\right)\right]$.

Vertical optical transitions were calculated on the optimized structures of $7 \mathbf{a}$ and 1a by time-dependent density functional theory (TD-DFT), using the software package Gaussian 03 (See Supporting Information for further details). ${ }^{42}$ The computed transition energies in both cases are slightly lower than the experimental values (Table S1 and S2). The spectra of mono and double POA-naphthazarin compounds 2a and $\mathbf{3}$ display low energy bands at $\lambda_{\max }=551 \mathrm{~nm}(2.25 \mathrm{eV}, \varepsilon=3180$ $\left.\mathrm{M}^{-1} \mathrm{~cm}^{-1}\right)$ and $\lambda_{\max }=557 \mathrm{~nm}\left(2.23 \mathrm{eV}, \varepsilon=3745 \mathrm{M}^{-1} \mathrm{~cm}^{-1}\right)$, respectively. Electrochemical analysis of these compounds reveals two quasireversible waves, consistent with literature studies (see Figure S114 and Table S5). ${ }^{43,44}$

Figure 3. (a) UV/vis spectra of selected compounds 1a (red line), 2a (black line), 3 (green line), and 7a (blue line) in $\mathrm{CH}_{2} \mathrm{Cl}_{2}$ at $298 \mathrm{~K}$. (b) Normalized absorbance (solid lines) and fluorescence (dashed lines) spectra of selected compounds $6 \mathbf{a}$ (red lines, $\lambda_{\mathrm{ex}}$ $=355 \mathrm{~nm}$ ), 8a (blue lines, $\lambda_{\mathrm{ex}}=355 \mathrm{~nm}$ ), and $\mathbf{1 0}$ (green lines, $\lambda_{\mathrm{ex}}=375 \mathrm{~nm}$ ) in $\mathrm{CH}_{2} \mathrm{Cl}_{2}$ at $298 \mathrm{~K}$. 
a)

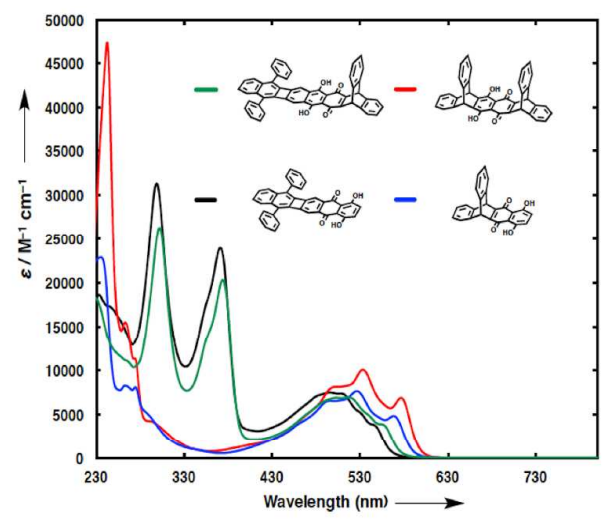

b)

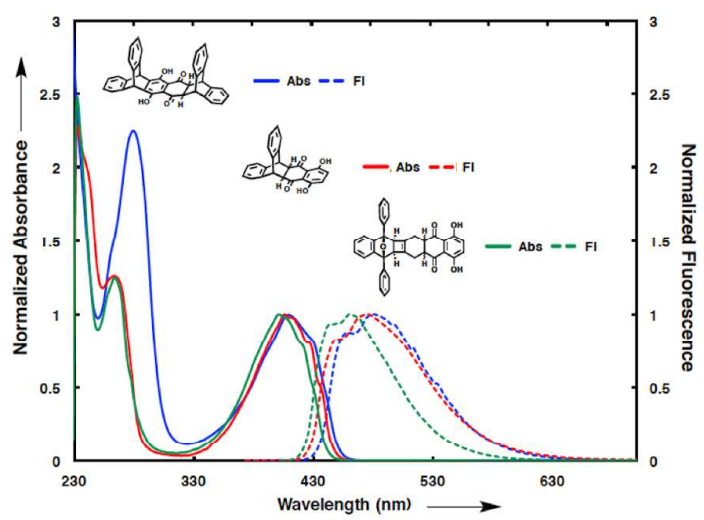

Upon analysis, some of the compounds synthesized in this study showed interesting fluorescent properties (Table 1 and Figure 3b). The unoxidized cycloaddition adducts (compounds $\mathbf{6 a}-\mathbf{d}, \mathbf{8 a}-\mathbf{d}$, and 10) showed strong blue fluorescence with high quantum yields $\left(\Phi_{\mathrm{F}}=0.58-0.91\right)$. Though fluorescent DielsAlder adducts of naphthazarin have been reported, ${ }^{45,46}$ the strong fluorescence of $\mathbf{6 a}-$ d, 8a-d, and $\mathbf{1 0}$ was unexpected due to the lack of $\pi$-conjugation across the backbone. This strong blue emission was observed across the series, suggesting it may be due to the enolizable nature or the hydrogen-bonding capabilities of the unoxidized naphthazarin adduct.

Table 1. Photophysical characterization of emissive compounds synthesized. All measurements were performed in $\mathrm{CH}_{2} \mathrm{Cl}_{2}\left(\lambda_{\mathrm{ex}}=375 \mathrm{~nm}\right)$.

\begin{tabular}{c|c|c|c|c|c} 
Entry & \multicolumn{1}{c}{ Compound } & $\left.\boldsymbol{\lambda}_{\max } \mathbf{( n m}\right)$ & $\boldsymbol{\varepsilon} \mathbf{M}^{-1} \mathbf{c m}^{-1} \mathbf{)}$ & $\left.\boldsymbol{\lambda}_{\mathrm{em}} \mathbf{( n m}\right)$ & $\Phi_{\mathrm{em}}$ \\
\hline & $\mathbf{6 a}$ & 432 & 3860 & 471 & 0.69 \\
1 & $\mathbf{6 b}$ & 434 & 2926 & 473 & 0.71 \\
2 & $\mathbf{6 c}$ & 432 & 3898 & 465 & 0.70 \\
3 & $\mathbf{6 d}$ & 435 & 3495 & 473 & 0.73 \\
4 & $\mathbf{8 a}$ & 429 & 4503 & 481 & 0.58 \\
5 & $\mathbf{8 b}$ & 433 & 8708 & 479 & 0.71 \\
6 & $\mathbf{8 c}$ & 431 & 6640 & 478 & 0.64 \\
7 & $\mathbf{8 d}$ & 434 & 7830 & 485 & 0.63 \\
8 & $\mathbf{1 0}$ & 421 & 4804 & 458 & 0.91 \\
9 & & & & &
\end{tabular}


Investigation of $\mathrm{BF}_{2}$-complexation with the naphthazarin-cores Complexation of $\mathrm{BF}_{3}-\mathrm{OEt}_{2}$ with the naphthazarin core of various synthesized compounds renders the molecules fully conjugated, and was explored for potential n-type semiconducting applications.

Representative complexation studies were conducted with ${ }^{1} \mathrm{H}$ NMR, UV/vis and mass spectroscopy. For example, we were able to observe the conversion of compound $\mathbf{1 a}$ to $\mathbf{B F}_{2} \mathbf{- 1 a}$ following the addition of $\mathrm{BF}_{3}-\mathrm{OEt}_{2}$ to $\mathbf{1 a}$ in $\mathrm{CH}_{2} \mathrm{Cl}_{2}$. The product could be isolated through precipitation and was analyzed by ${ }^{1} \mathrm{H}$ NMR as shown in Figure 4. Here, we observe the disappearance of the hydroxyl peak around $12 \mathrm{ppm}$, and see a distinct shift in the aromatic and bridgehead peaks upon complexation. Finally, a mixture of the two products clearly demonstrates the appearance of two discrete molecules in solution. The structure of $\mathbf{B} \mathbf{F}_{\mathbf{2}} \mathbf{- 1 a}$ was also confirmed by HR-ESI-MS ( $m / z$ calcd for $\mathrm{C}_{38} \mathrm{H}_{20} \mathrm{~B}_{2} \mathrm{~F}_{4} \mathrm{O}_{4}{ }^{-}$: 638.1518; found: 638.1503 $[\mathrm{M}]^{-}$) Susceptibility to hydrolysis was consistent with previous reports in the literature. ${ }^{28,29}$ Presumably due to moisture present in the air, hydrolysis was observed for $\mathbf{B F}_{2}-\mathbf{1 a}$ to occur in $\mathrm{CDCl}_{3}$ over 1-2 hours, precluding ${ }^{13} \mathrm{C}$ NMR analysis.

Figure 4. ${ }^{1} \mathrm{H}$ NMR spectra (400 MHz) of compounds $\mathbf{1 a}$ to $\mathrm{BF}_{2}-\mathbf{1 a}$ in $\mathrm{CDCl}_{3}$ at $298 \mathrm{~K}$ demonstrating $\mathrm{BF}_{2}$-complexation. 


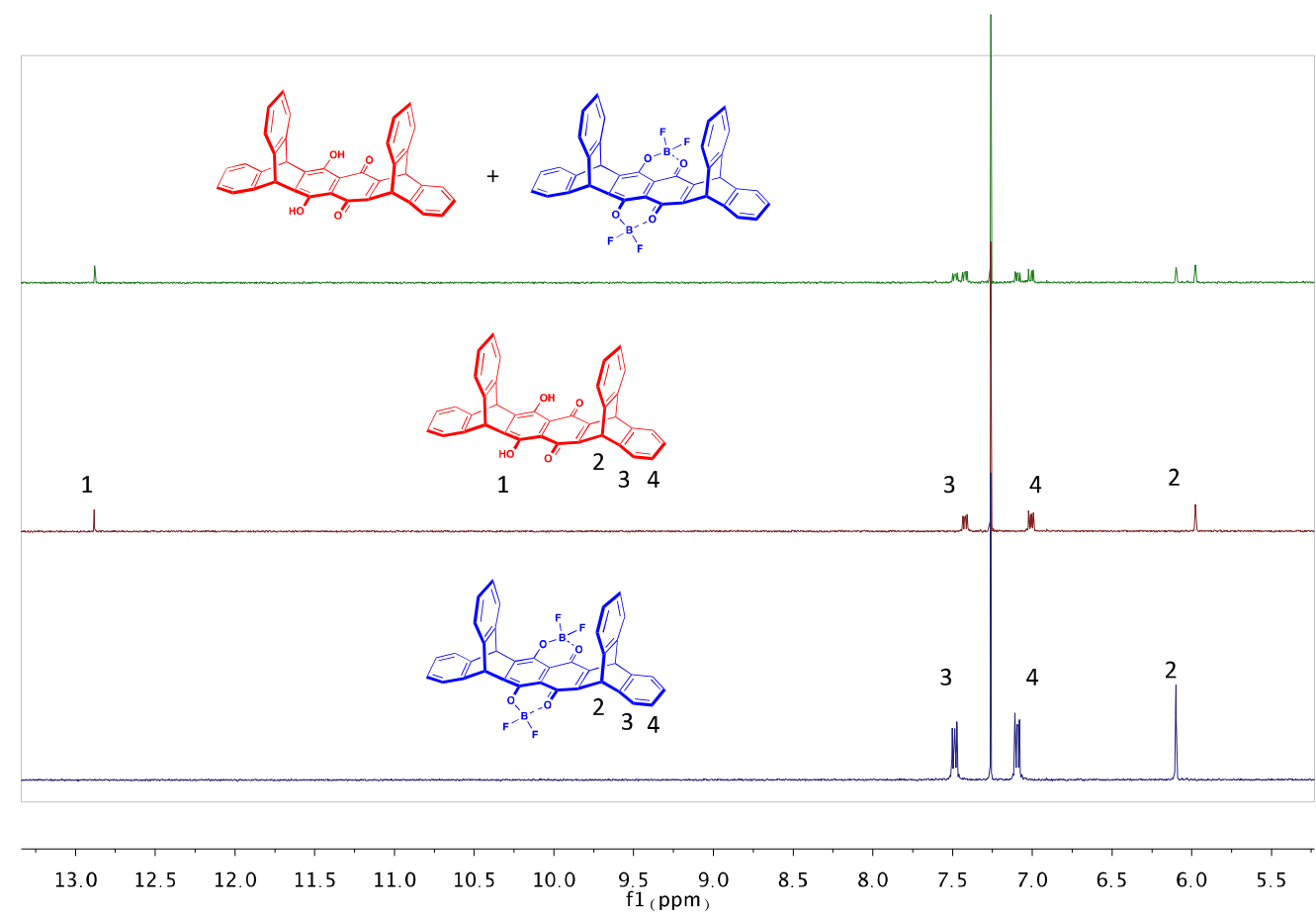

During the reaction of compound $\mathbf{1 a}$ with $\mathrm{BF}_{3}-\mathrm{OEt}_{2}$, the solution changed from dark red to dark purple, and was observed by UV/vis spectroscopy as a shift in absorbance bands from $\sim 533 \mathrm{~nm}$ to $\sim 561 \mathrm{~nm}$ (Figure 5). This red-shifted absorption maximum of $\mathbf{B F}_{2}-\mathbf{1 a}$ reveals the generation of a fully conjugated structure through $\mathrm{BF}_{2}$ chelation. Similar spectral changes were observed with $\mathbf{B F}_{\mathbf{2}} \mathbf{- 1} \mathbf{b}$ and $\mathbf{B} \mathbf{F}_{\mathbf{2}} \mathbf{- 1} \mathbf{c}$ (see Figures S39-42 in the SI for the UV/vis spectra of $\mathbf{B F}_{2}-\mathbf{- 1} \mathbf{b}$ and $\left.\mathbf{B} F_{2}-\mathbf{1} \mathbf{c}\right)$. In studying this complexation spectroscopically for $\mathbf{B} \mathbf{F}_{2}-\mathbf{2} \mathbf{a}$ and $\mathbf{B F}_{\mathbf{2}} \mathbf{- 3}$, our characterization attempts were hampered by the limited solubility of substrates $\mathbf{2 a}$ and $\mathbf{3}$, similar to that observed in literature. ${ }^{28,29}$ Despite this challenge, we were still able to observe a color change from orange to dark blue upon addition of $\mathrm{BF}_{3}-\mathrm{OEt}_{2}$, which was similar to that observed for the $\mathbf{B F}_{\mathbf{2}} \mathbf{- 1}$ series (See Figures S43-45 in the SI for the UV/vis spectra of $\mathbf{B F}_{2}-\mathbf{2 a}$ and $\left.\mathbf{B F}_{2}-3\right)$.

Figure 5. UV/vis spectra of compound $\mathbf{1 a}$ (black line) and $\mathbf{B F}_{\mathbf{2}} \mathbf{- 1 a}$ (blue line) in $\mathrm{CH}_{2} \mathrm{Cl}_{2}$ at $298 \mathrm{~K}$. 


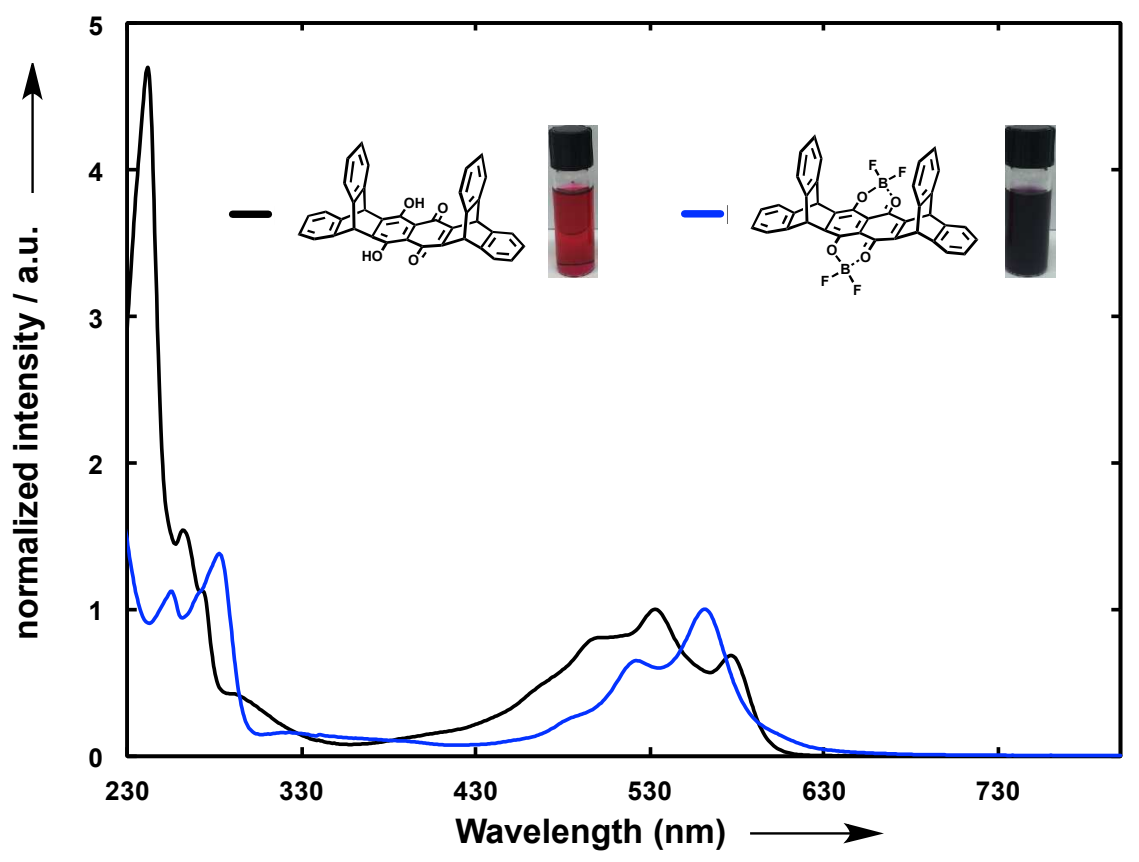




\section{CONCLUSION}

In conclusion, a selection of naphthazarin-containing polycyclic conjugated hydrocarbon molecules were synthesized and characterized, and may find utility in optoelectronic and other electronic applications. The molecular design includes 1) iptycene wings to add free space around the chromophores for better solubility, and 2) structural motifs of POAs to achieve improved stability. Successful coordination with $\mathrm{BF}_{2}$ as a proof-of-concept reveals the potential for new conjugated n-type electronic materials or expanded coordination complex structures, such as conducting metallopolymers.

\section{Experimental Section}

General. Reagents were purchased as reagent grade and used without further purification. All solvents were of ACS reagent grade or better. Toluene was passed through a solvent purification system via columns of activated alumina, and stored over $3 \AA$ sieves. Reactions in the absence of air and moisture were performed in ovendried glassware under $\mathrm{Ar}$ or $\mathrm{N}_{2}$ atmosphere. Flash column chromatography (FC) was performed using $\mathrm{SiO}_{2}(60 \AA, 230-400$ mesh, particle size $0.040-0.063 \mathrm{~mm})$ at $25{ }^{\circ} \mathrm{C}$ with a head pressure of $0.0-0.5$ bar. The used solvent compositions are reported individually in parentheses. Analytical thin layer chromatography (TLC) was performed on sheets coated with silica gel $(200 \mu \mathrm{m}$, IB-F). Visualization was achieved using UV light (254 or $366 \mathrm{~nm}$ ). Evaporation in vacuo was performed at 25 $60{ }^{\circ} \mathrm{C}$ and $900-10$ mbar. Reported yields refer to spectroscopically and chromatographically pure compounds that were dried under high vacuum (0.10.05 mbar) before analytical characterization. ${ }^{1} \mathrm{H}$ and ${ }^{13} \mathrm{C}$ nuclear magnetic resonance (NMR) spectra were recorded at 500 or $400 \mathrm{MHz}\left({ }^{1} \mathrm{H}\right)$ and 125 or $100 \mathrm{MHz}\left({ }^{13} \mathrm{C}\right)$, 
respectively. Chemical shifts $\delta$ are reported in ppm downfield from tetramethylsilane using the residual solvent signals as an internal reference $\left(\mathrm{CDCl}_{3}: \delta_{\mathrm{H}}=7.26 \mathrm{ppm}, \delta_{\mathrm{C}}\right.$ $\left.=77.16 \mathrm{ppm} / \mathrm{Cl}_{2} \mathrm{CDCDCl}_{2}: \delta_{\mathrm{H}}=6.0 \mathrm{ppm}, \delta_{\mathrm{C}}=73.78 \mathrm{ppm}\right)$. For ${ }^{1} \mathrm{H}$ NMR, coupling constants $J$ are given in $\mathrm{Hz}$ and the resonance multiplicity is described as s (singlet), d (doublet), t (triplet), q (quartet), quint (quintet), sext (sextet), sept (septet), m (multiplet), and br. (broad). All spectra were recorded at 298 K. High-resolution mass spectrometry (HRMS) was performed by the MS-service of the MIT Department of Chemistry Instrumentation Facility using an Ion Cyclotron Resonance Mass Spectrometer with either electrospray (ESI) or Direct Analysis in Real Time (DART) as the ionization technique. Where noted, additional mass spectra were obtaining using Matrix-Assisted Laser Desorption/Ionization-Time-of-Flight (MALDI-TOF)), by depositing samples directly onto the target without a matrix. UV/vis spectroscopy was recorded on a UV/vis spectrophotometer and corrected for background signal with a solvent-filled cuvette. Fluorescence spectra were measured using right-angle detection. Absolute quantum yield measurements were carried out using an integrating sphere, which was coupled to the fluorometer via an optical fiber bundle. Samples were excited with a $450 \mathrm{~W}$ Xenon short arc lamp and fluorescence was detected with a detector. All photophysical measurements were performed with spectral grade dichloromethane.

Naphthazarin (5) was used without further purification. Anthracene (4a) was recrystallized from ethanol/toluene prior to use. Compounds $\mathbf{4 b}(2,3,6,7-$ tetramethylanthracene) ${ }^{47} \mathbf{4 c}$ (2,6-di-tert-butylanthracene) ${ }^{48} \quad \mathbf{4 d} \quad(1,1,4,4,8,8,11,11$ Octamethyl-1,2,3,4,8,9,10,11-octahydro-pentacene), ${ }^{49}$ and diene $9^{11}$ were synthesized according to literature procedures.

\section{Monoadduct triptycene synthesis: Compounds 6a-d}


Naphthazarin (5) (1 equiv.) and the appropriate anthracene $4 a-d$ (1 equiv.) were added to a flame-dried Schlenk flask with stirrer bar, and were dissolved in the minimal amount of anhydrous toluene (1-2 mL). The headspace was purged with argon for 30 minutes, then heated to reflux overnight $\left(11{ }^{\circ} \mathrm{C}\right)$. The solvent was concentrated in vacuo. $\mathrm{FC}\left(\mathrm{SiO}_{2} ; \mathrm{CH}_{2} \mathrm{Cl}_{2}\right.$, or hexanes then $\mathrm{CH}_{2} \mathrm{Cl}_{2}$ in scenarios where separation was poor) gave target adducts $\mathbf{6 a}-\mathbf{d}$.

\section{Compound 6a}

Naphthazarin (5) (200 mg, $1.05 \mathrm{mmol})$, anthracene 4a (188 mg, $1.05 \mathrm{mmol})$, FC $\left(\mathrm{CH}_{2} \mathrm{Cl}_{2}\right)$ : 6a, yellow solid (241 mg, 62\% yield). Mp: $228-230{ }^{\circ} \mathrm{C} . \mathrm{R}_{\mathrm{f}}=0.66\left(\mathrm{CH}_{2} \mathrm{Cl}_{2}\right)$. ${ }^{1} \mathrm{H}$ NMR (400 MHz, $\mathrm{CDCl}_{3}$ ): $\delta 12.43$ (s, 2H), 7.45 (br. dd, 2H, $J=5.4,3.4 \mathrm{~Hz}$ ), 7.21 (br. dd, 2H, $J=5.4,3.4 \mathrm{~Hz}$ ), 7.15 (br. t, $2 \mathrm{H}, J=4.4 \mathrm{~Hz}$ ), 7.10 (s, 2H), 6.95 (br. t, $2 \mathrm{H}$, $J=4.4 \mathrm{~Hz}$ ), 5.04 (s, 2H), 3.35 ppm (br. s, $\left.2 \mathrm{H}) .{ }^{13} \mathrm{C} \mathrm{NMR} \mathrm{(101} \mathrm{MHz,} \mathrm{CDCl}_{3}\right): \delta 202.2$, $155.8,141.9,139.8,128.7,126.9,124.6,124.1,114.2,49.63,49.55 \mathrm{ppm} . \mathrm{UV} / \mathrm{vis}$ $\left(\mathrm{CH}_{2} \mathrm{Cl}_{2}\right): \lambda_{\max }(\varepsilon)=258(9371), 402(7438), 424(5973), 432 \mathrm{~nm}\left(3860 \mathrm{M}^{-1} \mathrm{~cm}^{-1}\right)$. HR-DART-MS: $m / z$ calcd for $\mathrm{C}_{24} \mathrm{H}_{15} \mathrm{O}_{4}^{-}: 367.0976$; found: $367.0970[\mathrm{M}-\mathrm{H}]^{-}$.

\section{Compound $6 b$}

Naphthazarin (5) (200 mg, $1.05 \mathrm{mmol})$, anthracene 4b (247 mg, $1.05 \mathrm{mmol})$, FC $\left(\mathrm{CH}_{2} \mathrm{Cl}_{2}\right)$ : 6b, yellow solid (205 mg, 53\% yield). Mp: 206-208 ${ }^{\circ} \mathrm{C} . \mathrm{R}_{\mathrm{f}}=0.74$ $\left(\mathrm{CH}_{2} \mathrm{Cl}_{2}\right) .{ }^{1} \mathrm{H}$ NMR (400 MHz, $\left.\mathrm{CDCl}_{3}\right): \delta 12.48(\mathrm{~s}, 2 \mathrm{H}), 7.19(\mathrm{~s}, 2 \mathrm{H}), 7.10(\mathrm{~s}, 2 \mathrm{H})$, $6.88(\mathrm{~s}, 2 \mathrm{H}), 4.89(\mathrm{~s}, 2 \mathrm{H}), 3.31(\mathrm{~s}, 2 \mathrm{H}), 2.23(\mathrm{~s}, 6 \mathrm{H}), 2.02 \mathrm{ppm}(\mathrm{s}, 6 \mathrm{H}) .{ }^{13} \mathrm{C}$ NMR $(101$ $\left.\mathrm{MHz}, \mathrm{CDCl}_{3}\right): \delta 202.6,155.8,140.0,137.7,134.7,128.5,125.7,125.2,114.4,50.0$, 48.6, 19.7, $19.6 \mathrm{ppm}$ (13 of 14 signals expected). UV/vis $\left(\mathrm{CH}_{2} \mathrm{Cl}_{2}\right): \lambda_{\max }(\varepsilon)=263$ (9368), 402 (6465), 425 (4931), $434 \mathrm{~nm}\left(2926 \mathrm{M}^{-1} \mathrm{~cm}^{-1}\right)$. HR-DART-MS: $\mathrm{m} / z$ calcd for $\mathrm{C}_{28} \mathrm{H}_{23} \mathrm{O}_{4}^{-}: 423.1602$; found: $423.1617[\mathrm{M}-\mathrm{H}]^{-}$.

\section{Compound 6c}


Naphthazarin (5) (100 mg, $0.53 \mathrm{mmol})$, anthracene $4 \mathbf{c}(153 \mathrm{mg}, 0.53 \mathrm{mmol}), \mathrm{FC}$ (100\% $n$-hexanes to $100 \% \mathrm{CH}_{2} \mathrm{Cl}_{2}$ ): $\mathbf{6 c}$, yellow solid (51 mg, $20 \%$ yield). Mp: $81-83$ ${ }^{\circ} \mathrm{C} . \mathrm{R}_{\mathrm{f}}=0.48\left(\mathrm{CH}_{2} \mathrm{Cl}_{2}\right) .{ }^{1} \mathrm{H}$ NMR $\left(400 \mathrm{MHz}, \mathrm{CDCl}_{3}\right): \delta 12.30(\mathrm{~s}, 1 \mathrm{H}), 12.26(\mathrm{~s}, 1 \mathrm{H})$, $7.47(\mathrm{~s}, 1 \mathrm{H}), 7.37$ (d, 1H, $J=7.8 \mathrm{~Hz}), 7.23$ (d, 1H, $J=7.7 \mathrm{~Hz}), 7.14(\mathrm{~s}, 1 \mathrm{H}), 7.05-$ $6.99(\mathrm{~m}, 3 \mathrm{H}), 6.91(\mathrm{~d}, 1 \mathrm{H}, J=7.8 \mathrm{~Hz}), 4.94(\mathrm{~s}, 1 \mathrm{H}), 4.91(\mathrm{~s}, 1 \mathrm{H}), 3.32(\mathrm{~s}, 2 \mathrm{H}), 1.32(\mathrm{~s}$, 9H), $1.10 \mathrm{ppm}(\mathrm{s}, 9 \mathrm{H}) .{ }^{13} \mathrm{C} \mathrm{NMR}\left(101 \mathrm{MHz}, \mathrm{CDCl}_{3}\right): \delta 202.88,202.86,155.4,155.3$, $150.1,150.0,141.6,139.5,138.5,136.6,128.24,128.19,124.0,123.7,123.5,123.3$, $121.7,121.2,114.40,114.36,50.5,50.3,50.2,50.0,34.9,34.6,31.7,31.4$ ppm. UV/vis $\left(\mathrm{CH}_{2} \mathrm{Cl}_{2}\right): \lambda_{\max }(\varepsilon)=260(12872), 403(7475), 432 \mathrm{~nm}\left(3898 \mathrm{M}^{-1} \mathrm{~cm}^{-1}\right) . \mathrm{HR}-$ DART-MS: $m / z$ calcd for $\mathrm{C}_{32} \mathrm{H}_{31} \mathrm{O}_{4}^{-}: 479.2228$; found: $479.2223[\mathrm{M}-\mathrm{H}]^{-}$.

\section{Compound 6d}

Naphthazarin (5) (100 mg, $0.53 \mathrm{mmol})$, anthracene 4d (210 mg, $0.56 \mathrm{mmol})$ : 6d, yellow solid (247 mg, 80\%). Mp: $260-262{ }^{\circ} \mathrm{C}$ (decomp.). $\mathrm{R}_{\mathrm{f}}=0.83\left(\mathrm{CH}_{2} \mathrm{Cl}_{2}\right) .{ }^{1} \mathrm{H}$ NMR (400 MHz, $\left.\mathrm{CDCl}_{3}\right): \delta 12.14(\mathrm{~s}, 2 \mathrm{H}), 7.34(\mathrm{~s}, 2 \mathrm{H}), 7.02(\mathrm{~s}, 2 \mathrm{H}), 6.98(\mathrm{~s}, 2 \mathrm{H})$, $4.77(\mathrm{~s}, 2 \mathrm{H}), 3.28$ (quasi t, 2H), $1.70-1.62(\mathrm{~m}, 4 \mathrm{H}), 1.49-1.38(\mathrm{~m}, 4 \mathrm{H}), 1.33(\mathrm{~s}$, 6H), $1.22(\mathrm{~s}, 6 \mathrm{H}), 1.11(\mathrm{~s}, 6 \mathrm{H}), 0.96 \mathrm{ppm}(\mathrm{s}, 6 \mathrm{H}) .{ }^{13} \mathrm{C} \mathrm{NMR}\left(101 \mathrm{MHz}, \mathrm{CDCl}_{3}\right): \delta$ $203.5,154.9,143.33,143.26,138.3,136.4,127.9,122.5,122.0,114.6,50.9,50.4$, $35.3,35.0,34.5,34.1,32.19,32.15,31.8,31.6 \mathrm{ppm} . \mathrm{UV} / \mathrm{vis}\left(\mathrm{CH}_{2} \mathrm{Cl}_{2}\right): \lambda_{\max }(\varepsilon)=263$ (11458), 403 (7872), 427 (5724), $435 \mathrm{~nm}\left(3495 \mathrm{M}^{-1} \mathrm{~cm}^{-1}\right)$. HR-DART-MS: $\mathrm{m} / z$ calcd for $\mathrm{C}_{40} \mathrm{H}_{43} \mathrm{O}_{4}^{-}:$587.3167; found: $587.3142[\mathrm{M}-\mathrm{H}]^{-}$.

\section{Oxidation to conjugated triptycene monoadducts: Compounds $7 \mathrm{a}-\mathrm{d}$.}

To a $25 \mathrm{~mL}$ round-bottom flask was added $\mathbf{6 a - d}$ ( 1 equiv.), $\mathrm{KO}^{t} \mathrm{Bu}$ (6 equiv.), and 20 $\mathrm{mL}$ THF. After stirring under ambient conditions for $1-3 \mathrm{~h}$, the blue reaction mixture was poured over $\mathrm{NH}_{4} \mathrm{Cl}$ (aq) and extracted with EtOAc. The organic layer was dried with $\mathrm{MgSO}_{4}$, filtered and evaporated. $\mathrm{FC}\left(\mathrm{SiO}_{2} ; \mathrm{CH}_{2} \mathrm{Cl}_{2}\right)$ gave $\mathbf{7 a - d}$ as a red solid. 


\section{Compound 7a}

6a (110 mg, $0.299 \mathrm{mmol}), \mathrm{KO}^{t} \mathrm{Bu}(201 \mathrm{mg}, 1.79 \mathrm{mmol})$ : 7a, red solid (107 mg, 98\% yield). Mp: $317-319^{\circ} \mathrm{C} . \mathrm{R}_{\mathrm{f}}=0.75\left(\mathrm{CH}_{2} \mathrm{Cl}_{2}\right) .{ }^{1} \mathrm{H} \mathrm{NMR}\left(400 \mathrm{MHz}, \mathrm{CDCl}_{3}\right): \delta 12.61(\mathrm{~s}$, 2H), 7.48 (br. dd, 4H, $J=5.3,3.3 \mathrm{~Hz}$ ), 7.09 (s, 2H), 7.06 (br. dd, 4H, $J=5.3,3.3 \mathrm{~Hz}$ ), $6.04 \mathrm{ppm}(\mathrm{s}, 2 \mathrm{H}) .{ }^{13} \mathrm{C} \mathrm{NMR}\left(101 \mathrm{MHz}, \mathrm{CDCl}_{3}\right): \delta 175.2,167.0,152.9,143.6,132.7$, 125.9, 124.6, 111.4, 47.6 ppm. UV/vis $\left(\mathrm{CH}_{2} \mathrm{Cl}_{2}\right): \lambda_{\max }(\varepsilon)=235$ (22860), $262(8250)$, 274 (8070), 496 (6520), 526 (7610), $568 \mathrm{~nm}\left(4800 \mathrm{M}^{-1} \mathrm{~cm}^{-1}\right)$. HR-DART-MS: $\mathrm{m} / \mathrm{z}$ calcd for $\mathrm{C}_{24} \mathrm{H}_{15} \mathrm{O}_{4}{ }^{+}$: 367.0965; found: $367.0954[\mathrm{M}+\mathrm{H}]^{+}$.

\section{Compound $7 b$}

6b (210 mg, $0.495 \mathrm{mmol}), \mathrm{KO}^{t} \mathrm{Bu}(333 \mathrm{mg}, 2.97 \mathrm{mmol})$ : 7b, red solid (159 mg, 76\% yield). Mp: $315-317^{\circ} \mathrm{C} . \mathrm{R}_{\mathrm{f}}=0.83\left(\mathrm{CH}_{2} \mathrm{Cl}_{2}\right) .{ }^{1} \mathrm{H} \mathrm{NMR}\left(400 \mathrm{MHz}, \mathrm{CDCl}_{3}\right): \delta 12.64(\mathrm{~s}$, 2H), $7.28(\mathrm{~s}, 4 \mathrm{H}), 7.09$ (s, 2H), $5.92(\mathrm{~s}, 2 \mathrm{H}), 2.20 \mathrm{ppm}(\mathrm{s}, 12 \mathrm{H}) .{ }^{13} \mathrm{C} \mathrm{NMR}(101 \mathrm{MHz}$, $\left.\mathrm{CDCl}_{3}\right): \delta 175.7,166.4,153.7,141.5,133.7,132.4,125.8,111.4,46.7,19.6$ ppm. UV/vis $\left(\mathrm{CH}_{2} \mathrm{Cl}_{2}\right): \lambda_{\max }(\varepsilon)=245$ (14350), 263 (15200), 283 (10700), 489 (4810), 526

(5610), $567 \mathrm{~nm}\left(3570 \mathrm{M}^{-1} \mathrm{~cm}^{-1}\right)$ HR-DART-MS: $\mathrm{m} / z$ calcd for $\mathrm{C}_{28} \mathrm{H}_{23} \mathrm{O}_{4}^{+}: 423.1591$; found: $423.1573[\mathrm{M}+\mathrm{H}]^{+}$.

\section{Compound $7 c$}

6c (40 mg, $0.083 \mathrm{mmol}), \mathrm{KO}^{t} \mathrm{Bu}(56 \mathrm{mg}, 0.499 \mathrm{mmol}): 7 \mathbf{c}$, red solid (39 mg, 99\% yield). Mp: $115-117{ }^{\circ} \mathrm{C} . \mathrm{R}_{\mathrm{f}}=0.58(\mathrm{DCM}) .{ }^{1} \mathrm{H}$ NMR (400 MHz, $\left.\mathrm{CDCl}_{3}\right): \delta 12.62(\mathrm{~s}$, 2H), 7.50 (s, 2H), 7.39 (d, 2H, J=7.9 Hz), 7.09 (s, 2H), 7.06 (d, 2H, $J=7.9 \mathrm{~Hz}), 5.97$ (s, 2H), $1.26 \mathrm{ppm}(\mathrm{s}, 18 \mathrm{H}) .{ }^{13} \mathrm{C} \mathrm{NMR}\left(101 \mathrm{MHz}, \mathrm{CDCl}_{3}\right): \delta 176.4,165.9,153.7$, $149.1,143.7,140.8,132.3,124.0,122.4,121.9,111.5,47.5,34.8,31.6$ ppm. UV/vis $\left(\mathrm{CH}_{2} \mathrm{Cl}_{2}\right): \lambda_{\max }(\varepsilon)=237$ (13700), 260 (7590), 278 (6480), 496 (3940), 526 (4590), $568 \mathrm{~nm}\left(2960 \mathrm{M}^{-1} \mathrm{~cm}^{-1}\right)$. HR-DART-MS: $\mathrm{m} / z$ calcd for $\mathrm{C}_{32} \mathrm{H}_{31} \mathrm{O}_{4}^{+}: 479.2217$; found: $479.2215[\mathrm{M}+\mathrm{H}]^{+}$. 


\section{Compound 7d}

6d (100 mg, $0.170 \mathrm{mmol}), \mathrm{KO}^{t} \mathrm{Bu}(114 \mathrm{mg}, 1.02 \mathrm{mmol}):$ 7d, red solid (85 mg, 85\% yield). Mp: $>350{ }^{\circ} \mathrm{C} \mathrm{R} \mathrm{R}_{\mathrm{f}}=0.84\left(\mathrm{CH}_{2} \mathrm{Cl}_{2}\right) .{ }^{1} \mathrm{H} \mathrm{NMR}\left(400 \mathrm{MHz}, \mathrm{CDCl}_{3}\right): \delta 12.62(\mathrm{~s}$, 2H), 7.39 (br. s, 4H), 7.05 (br. s, 2H), 5.88, (s, 2H), 1.62 (s, 8H), 1.24 ppm (s, 24H). ${ }^{13} \mathrm{C}$ NMR $\left(101 \mathrm{MHz}, \mathrm{CDCl}_{3}\right): \delta 177.8,164.6,154.0,142.2,140.6,131.7,122.6$, 111.6, 47.1, 35.2, 34.5, 32.1, 32.0 ppm. UV/vis $\left(\mathrm{CH}_{2} \mathrm{Cl}_{2}\right): \lambda_{\max }(\varepsilon)=240(16870), 273$ (12120), 284 (12600), 489 (6370), 526 (7630), $568 \mathrm{~nm}\left(4830 \mathrm{M}^{-1} \mathrm{~cm}^{-1}\right)$. HR-DARTMS: $m / z$ calcd for $\mathrm{C}_{40} \mathrm{H}_{42} \mathrm{O}_{4}^{+}: 587.3078$; found: $587.3083[\mathrm{M}+\mathrm{H}]^{+}$.

\section{Double-adduct pentiptycene synthesis: Compounds 8a-d}

Compound $7 \mathbf{a}-\mathbf{d}$ ( 1 equiv.) and the appropriate anthracene $4 \mathbf{a}-\mathbf{d}$ (1 equiv.) were added to a flame-dried Schlenk flask with stir bar, and were dissolved in the minimal amount of anhydrous toluene $(<1 \mathrm{~mL})$. The headspace was purged with argon for 30 minutes, then heated to reflux overnight $\left(111^{\circ} \mathrm{C}\right)$. The solvent that remained was concentrated in vacuo. $\mathrm{FC}\left(\mathrm{SiO}_{2} ; 100 \% n\right.$-hexanes to $\left.100 \% \mathrm{CH}_{2} \mathrm{Cl}_{2}\right)$.

\section{Compound 8a}

7a (36 mg, $0.098 \mathrm{mmol})$, 4a (17.5 mg, $0.098 \mathrm{mmol})$ : 8a, yellow solid (22 mg, 41\% yield). Mp: $190-192{ }^{\circ} \mathrm{C}$ (decomp). $\mathrm{R}_{\mathrm{f}}=0.89\left(\mathrm{CH}_{2} \mathrm{Cl}_{2}\right) .{ }^{1} \mathrm{H} \mathrm{NMR}\left(400 \mathrm{MHz}, \mathrm{CDCl}_{3}\right)$ : $\delta 12.75(\mathrm{~s}, 2 \mathrm{H}), 7.50-7.35(\mathrm{~m}, 6 \mathrm{H}), 7.17$ (quasi t, $2 \mathrm{H}, J=4.3 \mathrm{~Hz}$ ), 7.12 (quasi t, 2H, $J=4.3 \mathrm{~Hz}), 7.06-7.01(\mathrm{~m}, 2 \mathrm{H}), 7.01-6.97(\mathrm{~m}, 2 \mathrm{H}), 6.91-6.86(\mathrm{~m}, 2 \mathrm{H}), 5.99(\mathrm{~s}$, 2H), 5.05 (s, 2H), $3.27 \mathrm{ppm}(\mathrm{s}, 2 \mathrm{H}) .{ }^{13} \mathrm{C} \mathrm{NMR}\left(101 \mathrm{MHz}, \mathrm{CDCl}_{3}\right): \delta 201.9,151.2$, $145.5,144.1,143.8,142.1,140.0,126.9,126.7,125.74,125.72,124.6,124.4,124.3$, 124.0, 113.1, 49.5, 48.8, 47.6 ppm. UV/vis $\left(\mathrm{CH}_{2} \mathrm{Cl}_{2}\right): \lambda_{\max }(\varepsilon)=269$ (13378), 408 (5423), $429 \mathrm{~nm}\left(4503 \mathrm{M}^{-1} \mathrm{~cm}^{-1}\right)$. HR-DART-MS: $\mathrm{m} / z$ calcd for $\mathrm{C}_{38} \mathrm{H}_{23} \mathrm{O}_{4}^{-}$: 543.1602; found: $543.1620[\mathrm{M}-\mathrm{H}]^{-}$.

\section{Compound $8 b$}


7b (127 mg, $0.301 \mathrm{mmol}), \mathbf{4 b}(70 \mathrm{mg}, 0.301 \mathrm{mmol})$ : 8b, yellow solid (94 mg, 48\% yield). Mp: $249-251{ }^{\circ} \mathrm{C} . \mathrm{R}_{\mathrm{f}}=0.88\left(\mathrm{CH}_{2} \mathrm{Cl}_{2}\right) .{ }^{1} \mathrm{H} \mathrm{NMR}\left(400 \mathrm{MHz}, \mathrm{CDCl}_{3}\right): \delta 12.72(\mathrm{~s}$, 2H), $7.22(\mathrm{~s}, 2 \mathrm{H}), 7.17(\mathrm{~s}, 2 \mathrm{H}), 7.14(\mathrm{~s}, 2 \mathrm{H}), 6.82(\mathrm{~s}, 2 \mathrm{H}), 5.85(\mathrm{~s}, 2 \mathrm{H}), 4.87(\mathrm{~s}, 2 \mathrm{H})$, $3.21(\mathrm{~s}, 2 \mathrm{H}), 2.20(\mathrm{~s}, 6 \mathrm{H}), 2.16(\mathrm{~s}, 6 \mathrm{H}), 2.12(\mathrm{~s}, 6 \mathrm{H}), 1.91 \mathrm{ppm}(\mathrm{s}, 6 \mathrm{H}) .{ }^{13} \mathrm{C}$ NMR $(101$ $\left.\mathrm{MHz}, \mathrm{CDCl}_{3}\right): \delta 202.3,150.9,146.0,142.0,141.8,140.2,137.7,134.8,134.5,133.7$, $133.6,125.7,125.6,125.1,113.3,50.0,48.0,46.6,19.7,19.6,19.5 \mathrm{ppm}(21$ out of 23 signals expected). UV/vis $\left(\mathrm{CH}_{2} \mathrm{Cl}_{2}\right): \lambda_{\max }(\varepsilon)=279$ (27051), $409(11980), 433 \mathrm{~nm}$ (8708 $\left.\mathrm{M}^{-1} \mathrm{~cm}^{-1}\right)$. HR-DART-MS: $\mathrm{m} / z$ calcd for $\mathrm{C}_{46} \mathrm{H}_{40} \mathrm{O}_{4} \mathrm{Na}^{+}:$679.2819; found: $679.2826[\mathrm{M}+\mathrm{Na}]^{+}$

\section{Compound $8 \mathrm{c}$}

7c (40 mg, $0.084 \mathrm{mmol}), 4 c$ (24 mg, $0.084 \mathrm{mmol}): 8 c$, yellow solid (21 mg, 31\% yield). Mp: $220-222{ }^{\circ} \mathrm{C}$ (decomp.). $\mathrm{R}_{\mathrm{f}}=0.71\left(\mathrm{CH}_{2} \mathrm{Cl}_{2}\right)$. Note that by NMR we observe 4 isomers in a 1:1:1:1 ratio, based on the hydroxyl peak integration in the ${ }^{1} \mathrm{H}$ NMR spectrum.

${ }^{1} \mathrm{H}$ NMR (400 MHz, $\left.\mathrm{CDCl}_{3}\right): \delta 12.59$ (s, 2H), 12.57 (s, 2H), 12.55 (s, 2H), $12.54(\mathrm{~s}$, 2H), 7.43 (m, 12H), 7.36 (br. s, 2H), 7.31 (m, 12H), 7.20 (br. d, $J=1.86 \mathrm{~Hz}, 2 \mathrm{H}$ ), 7.18 (br. d, $J=1.86 \mathrm{~Hz}, 2 \mathrm{H}), 7.05(\mathrm{~m}, 4 \mathrm{H}), 7.02(\mathrm{~m}, 2 \mathrm{H}), 6.98(\mathrm{~m}, 8 \mathrm{H}), 6.74$ (dd, $J=$ 7.82, $2.01 \mathrm{~Hz}, 2 \mathrm{H}), 6.69(\mathrm{dd}, J=7.82,2.01 \mathrm{~Hz}, 2 \mathrm{H}), 5.88(\mathrm{~m}, 8 \mathrm{H}), 4.90(\mathrm{~m}, 8 \mathrm{H}), 3.23$ (m, 8H), $1.29(\mathrm{~m}, 36 \mathrm{H}), 1.26(\mathrm{~m}, 36 \mathrm{H}), 1.22(\mathrm{~m}, 36 \mathrm{H}), 0.87(\mathrm{~s}, 18 \mathrm{H}), 0.84(\mathrm{~s}, 18 \mathrm{H})$. ${ }^{13} \mathrm{C}$ NMR (101 MHz, $\left.\mathrm{CDCl}_{3}\right): \delta 202.73,202.68,150.6,150.55,150.53,150.4,149.9$, $149.83,149.78,148.8,148.7,145.7,145.6,144.23,144.17,143.8,143.7,141.7$, $141.6,141.4,141.3,140.9,139.5,139.4,138.84,138.77,136.7,123.9,123.7,123.6$, $123.5,123.4,123.1,123.0,122.4,122.19,122.17,121.8,121.6,121.4,121.2,121.1$, $113.2,113.12,113.07,50.1,50.0,49.9,49.8,47.4,36.8,34.84,34.75,34.4,34.3$, 31.69, 31.65, 31.59, 31.2. UV/vis $\left(\mathrm{CH}_{2} \mathrm{Cl}_{2}\right): \lambda_{\max }(\varepsilon)=275(21100), 410(8330), 431$ 
nm $\left(6640 \mathrm{M}^{-1} \mathrm{~cm}^{-1}\right)$. HR-ESI-MS: $\mathrm{m} / z$ calcd for $\mathrm{C}_{54} \mathrm{H}_{56} \mathrm{O}_{4} \mathrm{Na}^{+}$: 791.4071 ; found: $791.4055[\mathrm{M}+\mathrm{Na}]^{+}$.

\section{Compound 8d}

7d (61 mg, $0.104 \mathrm{mmol}), 4 d$ (41 mg, $0.104 \mathrm{mmol})$ : 8d, yellow solid (62 mg, 61\%). $\mathrm{Mp}:>350{ }^{\circ} \mathrm{C} . \mathrm{R}_{\mathrm{f}}=0.97\left(\mathrm{CH}_{2} \mathrm{Cl}_{2}\right) .{ }^{1} \mathrm{H} \mathrm{NMR}\left(400 \mathrm{MHz}, \mathrm{CDCl}_{3}\right): \delta 12.42(\mathrm{~s}, 2 \mathrm{H}), 7.31$ (s, 4H), $7.27(\mathrm{~s}, 2 \mathrm{H}), 6.89(\mathrm{~s}, 2 \mathrm{H}), 5.77(\mathrm{~s}, 2 \mathrm{H}), 4.72(\mathrm{~s}, 2 \mathrm{H}), 3.18(\mathrm{~s}, 2 \mathrm{H}), 1.70-1.60$ $(\mathrm{m}, 8 \mathrm{H}), 1.57(\mathrm{~s}, 4 \mathrm{H}), 1.40-1.10(\mathrm{~m}, 38 \mathrm{H}), 1.00(\mathrm{~s}, 6 \mathrm{H}), 0.74(\mathrm{~m}, 2 \mathrm{H}), 0.62 \mathrm{ppm}(\mathrm{s}$, $6 \mathrm{H}) .{ }^{13} \mathrm{C} \mathrm{NMR}\left(101 \mathrm{MHz}, \mathrm{CDCl}_{3}\right): \delta 203.6,150.1,145.5,143.2,143.0,141.7,141.5$, $140.6,138.1,136.2,128.4,122.5,122.4,122.1,122.0,113.0,51.1,50.4,47.0,35.4$, $35.3,34.6,34.46,34.45,34.4,33.9,32.5,32.2,32.1,32.0,31.9,31.8,31.50$ ppm. UV/vis $\left(\mathrm{CH}_{2} \mathrm{Cl}_{2}\right): \lambda_{\max }(\varepsilon)=279(25616), 411(10015), 434 \mathrm{~nm}\left(7830 \mathrm{M}^{-1} \mathrm{~cm}^{-1}\right) . \mathrm{HR}-$ ESI-MS: $m / z$ calcd for $\mathrm{C}_{70} \mathrm{H}_{80} \mathrm{O}_{4} \mathrm{Na}^{+}$: 1007.5949 ; found: $1007.5963[\mathrm{M}+\mathrm{Na}]^{+}$.

\section{Oxidation to conjugated pentiptycene double-adducts 1a-c.}

To a $25 \mathrm{~mL}$ round-bottom flask was added $\mathbf{8 a}-\mathbf{c}$ ( 1 equiv.), $\mathrm{KO}^{t} \mathrm{Bu}$ (6 equiv.), and 20 $\mathrm{mL}$ THF. After stirring under ambient conditions for $1-3 \mathrm{~h}$, the blue reaction mixture was poured over $\mathrm{NH}_{4} \mathrm{Cl}$ (aq) and extracted with EtOAc. The organic layer was dried with $\mathrm{MgSO}_{4}$, filtered and evaporated. $\mathrm{FC}\left(\mathrm{SiO}_{2} ; \mathrm{CH}_{2} \mathrm{Cl}_{2}\right)$ gave $\mathbf{1 a - d}$ as a red solid.

\section{Compound 1a}

8a (55 mg, $0.101 \mathrm{mmol}), \mathrm{KO}^{t} \mathrm{Bu}(68 \mathrm{mg}, 0.606 \mathrm{mmol})$ : 1a, red solid (38 mg, 69\% yield). Mp: $>350{ }^{\circ} \mathrm{C} . \mathrm{R}_{\mathrm{f}}=0.91\left(\mathrm{CH}_{2} \mathrm{Cl}_{2}\right) \cdot{ }^{1} \mathrm{H}$ NMR (400 MHz, $\left.\mathrm{CDCl}_{3}\right): \delta 12.88(\mathrm{~s}$, 2H), 7.42 (br. dd, $8 \mathrm{H}, J=5.3,3.2 \mathrm{~Hz}$ ), 7.01 (br. dd, $8 \mathrm{H}, J=5.3,3.2 \mathrm{~Hz}$ ), 5.98 ppm (s, 4H). ${ }^{13} \mathrm{C} \mathrm{NMR}\left(101 \mathrm{MHz}, \mathrm{CDCl}_{3}\right): \delta 169.1,151.1,143.7,125.8,124.5,110.2,47.6$ ppm. UV/vis $\left(\mathrm{CH}_{2} \mathrm{Cl}_{2}\right): \lambda_{\max }(\varepsilon)=242$ (47370), 262 (15520), 291 (4270), 502 (8140), 533 (10070), $576 \mathrm{~nm}\left(6900 \mathrm{M}^{-1} \mathrm{~cm}^{-1}\right)$. HR-DART-MS: $\mathrm{m} / z$ calcd for $\mathrm{C}_{38} \mathrm{H}_{23} \mathrm{O}_{4}{ }^{+}$: 543.1591; found: $543.1583[\mathrm{M}+\mathrm{H}]^{+}$. 


\section{Compound $1 b$}

8b (94 mg, $0.143 \mathrm{mmol}), \mathrm{KO}^{t} \mathrm{Bu}(96 \mathrm{mg}, 0.859 \mathrm{mmol})$ : 1b, red solid (51 mg, 54\% yield). Mp: $>350{ }^{\circ} \mathrm{C} . \mathrm{R}_{\mathrm{f}}=0.80\left(\mathrm{CH}_{2} \mathrm{Cl}_{2}\right) .{ }^{1} \mathrm{H}$ NMR (400 MHz, $\left.\mathrm{CDCl}_{3}\right): \delta 12.87(\mathrm{~s}$, 2H), $7.18(\mathrm{~s}, 8 \mathrm{H}), 5.82(\mathrm{~s}, 4 \mathrm{H}), 2.13 \mathrm{ppm}(\mathrm{s}, 24 \mathrm{H}) .{ }^{13} \mathrm{C} \mathrm{NMR}\left(101 \mathrm{MHz}, \mathrm{CDCl}_{3}\right): \delta$ 169.0, 151.6, 141.7, 133.5, 125.7, 110.1, 46.7, $19.6 \mathrm{ppm} . \mathrm{UV} / \mathrm{vis}\left(\mathrm{CH}_{2} \mathrm{Cl}_{2}\right): \lambda_{\max }(\varepsilon)=$ 248 (30200), 273 (20415), 283 (17150), 502 (7500), 534 (9160), 577 nm (6420 M $\mathrm{cm}^{-1}$ ). HR-DART-MS: $\mathrm{m} / z$ calcd for $\mathrm{C}_{46} \mathrm{H}_{39} \mathrm{O}_{4}{ }^{+}: 655.2843$; found: $655.2856[\mathrm{M}+$ $\mathrm{H}]^{+}$.

\section{Compound 1c}

8c (111 mg, $0.144 \mathrm{mmol}), \mathrm{KO}^{\mathrm{t}} \mathrm{Bu}(97 \mathrm{mg}, 0.866 \mathrm{mmol}):$ 1c, red solid (50 mg, 45\% yield). Mp: $264-266{ }^{\circ} \mathrm{C} . \mathrm{R}_{\mathrm{f}}=0.97\left(\mathrm{CH}_{2} \mathrm{Cl}_{2}\right) .{ }^{1} \mathrm{H} \mathrm{NMR}\left(400 \mathrm{MHz}, \mathrm{CDCl}_{3}\right): \delta 12.95(\mathrm{~s}$, 2H), 7.46 (s, 4H), 7.36 (br. d, 4H, $J=7.7 \mathrm{~Hz}$ ), 7.03 (br. d, 4H, $J=7.7 \mathrm{~Hz}$ ), 5.94 (s, 4H), $1.25 \mathrm{ppm}(\mathrm{s}, 36 \mathrm{H}) .{ }^{13} \mathrm{C} \mathrm{NMR}\left(101 \mathrm{MHz}, \mathrm{CDCl}_{3}\right): \delta 169.2,151.6,148.9,143.8$, $140.9,123.8,122.3,121.7,110.1,47.5,34.8,31.6 \mathrm{ppm} . \mathrm{UV} / \mathrm{vis}\left(\mathrm{CH}_{2} \mathrm{Cl}_{2}\right): \lambda_{\max }(\varepsilon)=$ 245 (41075), 267 (19620), 278 (15230), 504 (8130), 533 (10010), 577 nm (6910 M $\mathrm{cm}^{-1}$ ). HR-ESI-MS: $\mathrm{m} / z$ calcd for $\mathrm{C}_{54} \mathrm{H}_{55} \mathrm{O}_{4}{ }^{+}:$767.4095; found: $767.4088[\mathrm{M}+\mathrm{H}]^{+}$. Synthesis of the POA series

\section{Compound 10}

Naphthazarin (5) (100 mg, $0.526 \mathrm{mmol})$ and diene 9 (238 mg, $0.684 \mathrm{mmol})$ were added to either an oven-dried pressure tube or flame-dried Schlenk flask with stirrer bar, and were dissolved in the minimal amount of anhydrous toluene (1-2 mL). The headspace was purged with argon for 30 minutes, then heated to reflux overnight (111 $\left.{ }^{\circ} \mathrm{C}\right)$. The solvent was concentrated in vacuo. Gravity column chromatography $\left(\mathrm{SiO}_{2}\right.$ : $\left.\mathrm{CH}_{2} \mathrm{Cl}_{2}\right)$ or $\mathrm{FC}\left(\mathrm{SiO}_{2} ; 100 \% n\right.$-hexanes to $\left.100 \% \mathrm{CH}_{2} \mathrm{Cl}_{2}\right)$ yielded $138 \mathrm{mg}$ (49\% yield) of a yellow solid. Note that while the highest yields were obtained when carried out in 
a pressure tube, similar yields are obtained when carried out under refluxing conditions. Note also that by NMR we observe 1:0.20:0.20 ratio of isomers, based on the hydroxyl peaks. The ${ }^{1} \mathrm{H}$ NMR integrations are calculated such that hydroxyl peaks in 11.94-11.79 integrate to a total of $2 \mathrm{H}$. Mp: $301-303{ }^{\circ} \mathrm{C} . \mathrm{R}_{\mathrm{f}}=0.32$ (DCM).

${ }^{1} \mathrm{H}$ NMR (400 MHz, $\left.\mathrm{CDCl}_{3}\right): \delta 11.94(\mathrm{~s}, 0.28 \mathrm{H}), 11.90$ (s, $\left.0.28 \mathrm{H}\right), 11.78(\mathrm{~s}, 1.43 \mathrm{H})$, 7.66 (m, 4 H), 7.44 (m, 6 H), 7.20 (s, 2 H), 7.12 (m, 2 H), 6.95 (m, 2 H), 3.47 (m, 2 $\mathrm{H}), 3.13$ (m, $2 \mathrm{H}), 2.20$ (m, $4 \mathrm{H}) .{ }^{13} \mathrm{C} \mathrm{NMR}\left(101 \mathrm{MHz}, \mathrm{CDCl}_{3}\right): \delta 203.5,202.7,155.3$, $155.2,155.1,148.1,140.7,140.5,137.2,137.1,128.7,128.62,128.57,128.51,128.4$, $128.3,128.2,128.16,128.1,127.0,126.9,126.8,119.4,119.3,113.4,86.43,86.39$, 86.3, 54.0, 53.6, 53.3, 46.3, 46.0, 45.8, 25.4, 24.8, 23.7. UV/vis $\left(\mathrm{CH}_{2} \mathrm{Cl}_{2}\right): \lambda_{\max }(\varepsilon)=$ 259 (8606), 398 (6903), $421 \mathrm{~nm}\left(4804 \mathrm{M}^{-1} \mathrm{~cm}^{-1}\right)$. HR-DART-MS: $\mathrm{m} / z$ calcd for $\mathrm{C}_{36} \mathrm{H}_{27} \mathrm{O}_{5}^{+}$: 539.1853, found 539.1852 [M+H] $]^{+}$.

\section{Compound 11}

To a $25 \mathrm{~mL}$ round-bottom flask was added $10(330 \mathrm{mg}, 0.613 \mathrm{mmol})$ and $\mathrm{KO}^{t} \mathrm{Bu}(206$ $\mathrm{mg}, 1.84 \mathrm{mmol})$ in $20 \mathrm{~mL}$ THF. The reaction was stirred under ambient conditions for 1-5 min, and was monitored by TLC for the appearance of the red partially oxidized product $\mathbf{1 1}$ and stopped immediately following the appearance of the orange fully oxidized 12. The dark blue reaction mixture was poured over $\mathrm{NH}_{4} \mathrm{Cl}$ (aq) and extracted with EtOAc. The organic layer was dried with $\mathrm{MgSO}_{4}$, filtered and evaporated. FC $\left(\mathrm{SiO}_{2} ; \mathrm{CH}_{2} \mathrm{Cl}_{2}\right)$ gave 11 as a red solid (171 mg, 52\% yield). Mp: $293-$ $295{ }^{\circ} \mathrm{C} . \mathrm{R}_{\mathrm{f}}=0.40\left(\mathrm{CH}_{2} \mathrm{Cl}_{2}\right) .{ }^{1} \mathrm{H}$ NMR $\left(400 \mathrm{MHz}, \mathrm{CDCl}_{3}\right): \delta 12.41(\mathrm{~s}, 2 \mathrm{H}), 7.70(\mathrm{~d}$, $4 \mathrm{H}, J=6.9 \mathrm{~Hz}), 7.50(\mathrm{t}, 4 \mathrm{H}, J=7.4 \mathrm{~Hz}), 7.45-7.39(\mathrm{~m}, 2 \mathrm{H}), 7.19-7.07(\mathrm{~m}, 4 \mathrm{H})$, $6.98(\mathrm{dd}, 2 \mathrm{H}, J=5.3,3.0 \mathrm{~Hz}), 3.62(\mathrm{~s}, 2 \mathrm{H}), 3.18-3.05(\mathrm{~m}, 2 \mathrm{H}), 2.87-2.74 \mathrm{ppm}(\mathrm{m}$, 2H). $\left.{ }^{13} \mathrm{C} \mathrm{NMR} \mathrm{(101} \mathrm{MHz,} \mathrm{CDCl}_{3}\right): \delta 186.3,158.6,148.1,143.9,138.5,137.0,129.6$, $128.7,128.3,127.0,126.8,119.4,111.4,86.4,54.0,24.2 \mathrm{ppm} . \mathrm{UV} / \mathrm{vis}\left(\mathrm{CH}_{2} \mathrm{Cl}_{2}\right): \lambda_{\max }$ 
$(\varepsilon)=279$ (7718), 482 (6380), $511(7071), 550 \mathrm{~nm}\left(4181 \mathrm{M}^{-1} \mathrm{~cm}^{-1}\right)$. HR-DART-MS:

$m / z$ calcd for $\mathrm{C}_{36} \mathrm{H}_{25} \mathrm{O}_{5}^{+}:$537.1697; found: $537.1684[\mathrm{M}+\mathrm{H}]^{+}$.

\section{Compound 12}

To a $25 \mathrm{~mL}$ round-bottom flask was added $10(105 \mathrm{mg}, 0.195 \mathrm{mmol})$ and $\mathrm{KO}^{t} \mathrm{Bu}(394$ $\mathrm{mg}, 3.51 \mathrm{mmol}$ ) in $20 \mathrm{~mL}$ THF. After stirring under ambient conditions for $1-3 \mathrm{~h}$, the blue reaction mixture was poured over $\mathrm{NH}_{4} \mathrm{Cl}$ (aq) and extracted with EtOAc. The organic layer was dried with $\mathrm{MgSO}_{4}$, filtered and evaporated. $\mathrm{FC}\left(\mathrm{SiO}_{2} ; \mathrm{CH}_{2} \mathrm{Cl}_{2}\right)$ gave 12 as an orange solid (81 mg, 78\% yield). Mp: $304-305{ }^{\circ} \mathrm{C} . \mathrm{R}_{\mathrm{f}}=0.47\left(\mathrm{CH}_{2} \mathrm{Cl}_{2}\right) .{ }^{1} \mathrm{H}$ NMR (400 MHz, $\left.\mathrm{CDCl}_{3}\right): \delta 12.80(\mathrm{~s}, 2 \mathrm{H}), 7.75-7.70(\mathrm{~m}, 6 \mathrm{H}), 7.56-7.52(\mathrm{~m}, 4 \mathrm{H})$, $7.49-7.44(\mathrm{~m}, 2 \mathrm{H}), 7.22(\mathrm{dd}, 2 \mathrm{H}, J=5.4,3.0 \mathrm{~Hz}), 7.19(\mathrm{~s}, 2 \mathrm{H}), 7.11(\mathrm{dd}, 2 \mathrm{H}, J=5.4$, 3.0 Hz), $4.34 \mathrm{ppm}(\mathrm{s}, 2 \mathrm{H}) .{ }^{13} \mathrm{C} \mathrm{NMR}\left(101 \mathrm{MHz}, \mathrm{CDCl}_{3}\right): \delta 187.1,157.7,151.0,147.5$, $135.7,134.5,129.2,128.9,128.6,127.5,126.8,121.2,119.7,112.5,89.0,55.7$ ppm. UV/vis $\left(\mathrm{CH}_{2} \mathrm{Cl}_{2}\right): \lambda_{\max }(\varepsilon)=275(38000), 486 \mathrm{~nm}\left(8080 \mathrm{M}^{-1} \mathrm{~cm}^{-1}\right)$. HR-DART-MS: $m / z$ calcd for $\mathrm{C}_{36} \mathrm{H}_{23} \mathrm{O}_{5}^{+}:$535.1540; found: $535.1541[\mathrm{M}+\mathrm{H}]^{+}$.

\section{Compound $2 a$}

In a flame-dried $25 \mathrm{~mL}$ Schlenk flask, compound 12 (21 mg, $0.039 \mathrm{mmol})$ was dissolved in 1:1 isopropyl alcohol- $\mathrm{CHCl}_{3}(0.5 \mathrm{~mL}$ each). Concentrated $\mathrm{HCl}(0.2 \mathrm{~mL})$ was added slowly to the solution under argon. The solution was heated to $80{ }^{\circ} \mathrm{C}$ for 4 hours. The product was washed with deionized water and extracted with $\mathrm{CH}_{2} \mathrm{Cl}_{2}$, then concentrated in vacuo. The product was washed with hexanes, then filtered and dried overnight under vacuum, affording $2 \mathbf{2}$ as a red solid (17 mg, 84\% yield). Mp: $>350$ ${ }^{\circ} \mathrm{C} . \mathrm{R}_{\mathrm{f}}=0.53\left(\mathrm{CH}_{2} \mathrm{Cl}_{2}\right) .{ }^{1} \mathrm{H} \mathrm{NMR}\left(400 \mathrm{MHz}, \mathrm{CDCl}_{3}\right): \delta 12.88(\mathrm{~s}, 2 \mathrm{H}), 7.87(\mathrm{dd}, 2 \mathrm{H}, J$ $=6.3,3.4 \mathrm{~Hz}), 7.65-7.60(\mathrm{~m}, 8 \mathrm{H}), 7.56(\mathrm{~s}, 2 \mathrm{H}), 7.55-7.50(\mathrm{~m}, 2 \mathrm{H}), 7.37(\mathrm{dd}, 2 \mathrm{H}, J$ $=6.3,3.4 \mathrm{~Hz}), 7.27 \mathrm{ppm}(\mathrm{s}, 2 \mathrm{H}) . \mathrm{UV} / \mathrm{vis}\left(\mathrm{CH}_{2} \mathrm{Cl}_{2}\right): \lambda_{\mathrm{abs}}(\varepsilon)=298(31300), 370$ 
(23900), 511 (7270), $551 \mathrm{~nm}\left(3180 \mathrm{M}^{-1} \mathrm{~cm}^{-1}\right)$. HR-DART-MS: $\mathrm{m} / z$ calcd for $\mathrm{C}_{36} \mathrm{H}_{21} \mathrm{O}_{4}^{+}:$517.1434; found: $517.1422[\mathrm{M}+\mathrm{H}]^{+}$.

\section{Compound $2 b$}

In a flame-dried $25 \mathrm{~mL}$ Schlenk flask, compound 12 (154 mg, $0.288 \mathrm{mmol})$ was dissolved in $10 \mathrm{~mL}$ acetic anhydride with $p$-TsOH crystals (694 mg, $4.0 \mathrm{mmol}$ ). The solution was heated to $120{ }^{\circ} \mathrm{C}$ for 12 hours. The product was precipitated by pouring solution over ice, and adding water until a solid precipitate formed. The product was filtered and dried overnight under vacuum, affording $\mathbf{2 b}$ as an orange solid (100 $\mathrm{mg}$, 58\% yield). Mp: $285-287{ }^{\circ} \mathrm{C} . \mathrm{R}_{\mathrm{f}}=0.33\left(\mathrm{CH}_{2} \mathrm{Cl}_{2}\right) .{ }^{1} \mathrm{H}$ NMR $\left(400 \mathrm{MHz}, \mathrm{CDCl}_{3}\right): \delta$ $7.84(\mathrm{dd}, 2 \mathrm{H}, J=6.2,3.4 \mathrm{~Hz}), 7.62-7.57(\mathrm{~m}, 8 \mathrm{H}), 7.55-7.48(\mathrm{~m}, 2 \mathrm{H}), 7.40-7.32$ (m, 6H), 2.45 ppm (s, 6H). ${ }^{13} \mathrm{C}$ NMR (101 MHz, $\left.\mathrm{CDCl}_{3}\right): \delta$ 183.3, 169.6, 155.7, $148.1,142.2,136.1,135.7,135.2,131.5,130.9,129.6,129.1,128.5,127.6,127.4$, 125.8, 115.3, 21.3 ppm. UV/vis $\left(\mathrm{CH}_{2} \mathrm{Cl}_{2}\right): \lambda_{\max }(\varepsilon)=299$ (41950), 368 (39395), 463 nm $\left(2878 \mathrm{M}^{-1} \mathrm{~cm}^{-1}\right)$. HR-DART-MS: $\mathrm{m} / z$ calcd for $\mathrm{C}_{40} \mathrm{H}_{25} \mathrm{O}_{6}^{+}$: 601.1646; found: $601.1643[\mathrm{M}+\mathrm{H}]^{+}$.

\section{Compound 13}

11 (32 mg, $0.060 \mathrm{mmol})$ and diene $9(21 \mathrm{mg}, 0.060 \mathrm{mmol})$ were added to a flamedried Schlenk flask with stir bar, and were dissolved in the minimal amount of anhydrous toluene (1-2 mL). The headspace was purged with argon for 30 minutes, then heated to reflux overnight $\left(111^{\circ} \mathrm{C}\right)$. The solvent was concentrated in vacuo. $\mathrm{KO}^{t} \mathrm{Bu}(121 \mathrm{mg}, 1.07 \mathrm{mmol})$ and $20 \mathrm{~mL}$ THF were added to the flask, and the reaction was allowed to stir $1-3 \mathrm{~h}$ under ambient conditions. The blue reaction mixture was then poured over $\mathrm{NH}_{4} \mathrm{Cl}(\mathrm{aq})$ and extracted with EtOAc. The organic layer was dried with $\mathrm{MgSO}_{4}$, filtered and evaporated. Gravity column chromatography $\left(\mathrm{SiO}_{2}: \mathrm{CH}_{2} \mathrm{Cl}_{2}\right)$ gave $13(7 \mathrm{mg}, 13 \%$ yield) as an orange solid. $\mathrm{Mp}$ : 
315-317 ${ }^{\circ} \mathrm{C} . \mathrm{R}_{\mathrm{f}}=0.75\left(\mathrm{CH}_{2} \mathrm{Cl}_{2}\right) .{ }^{1} \mathrm{H}$ NMR $\left(400 \mathrm{MHz}, \mathrm{CDCl}_{3}\right): \delta 15.03(\mathrm{~s}, 2 \mathrm{H}), 7.80$ (s, 4H), $7.75-7.71(\mathrm{~m}, 8 \mathrm{H}), 7.52(\mathrm{t}, 8 \mathrm{H}, J=7.4 \mathrm{~Hz}), 7.47-7.42(\mathrm{~m}, 4 \mathrm{H}), 7.20(\mathrm{dd}$, $4 \mathrm{H}, J=5.4,3.0 \mathrm{~Hz}), 7.09(\mathrm{dd}, 4 \mathrm{H}, J=5.4,3.0 \mathrm{~Hz}), 4.34 \mathrm{ppm}(\mathrm{s}, 4 \mathrm{H}) .{ }^{13} \mathrm{C} \mathrm{NMR}(100$ $\left.\mathrm{MHz}, \mathrm{CDCl}_{3}\right): \delta 179.6,172.7,148.8,147.8,135.9,133.3,128.8,128.5,127.4,126.9$, $120.1,119.7,113.6,105.8,89.2,55.5 \mathrm{ppm} . \mathrm{UV} / \mathrm{vis}\left(\mathrm{CH}_{2} \mathrm{Cl}_{2}\right): \lambda_{\max }(\varepsilon)=285(76508)$, 491 (24618), 462 (15226), 315 (24907), $526 \mathrm{~nm}\left(22821 \mathrm{M}^{-1} \mathrm{~cm}^{-1}\right)$. HR-DART-MS: $m / z$ calcd for $\mathrm{C}_{62} \mathrm{H}_{38} \mathrm{O}_{6} \mathrm{Na}^{+}: 901.2561$; found: $901.2549[\mathrm{M}+\mathrm{Na}]^{+}$.

\section{Compound 14}

In a flame-dried $25 \mathrm{~mL}$ Schlenk flask, compound 13 (21 mg, $0.039 \mathrm{mmol})$ was dissolved in 1:1 isopropyl alcohol- $\mathrm{CHCl}_{3}(0.5 \mathrm{~mL}$ each). Concentrated $\mathrm{HCl}(0.2 \mathrm{~mL})$ was added slowly to the solution under argon. The solution was heated to $80{ }^{\circ} \mathrm{C}$ for four hours. The product was washed with deionized water and extracted with $\mathrm{CH}_{2} \mathrm{Cl}_{2}$, then concentrated in vacuo, affording insoluble dark colored solid. Poor solubility and decomposition precluded further characterization beyond mass detection by MALDITOF. MALDI-TOF-MS: $m / z$ calcd for $\mathrm{C}_{62} \mathrm{H}_{34} \mathrm{O}_{4}{ }^{+}: 842.24$, found $842.08[\mathrm{M}]^{+}$(See S112-113. for mass spectrum).

\section{Iptycene-POAs}

\section{Compound 15}

$7 \mathbf{a}(90 \mathrm{mg}, 0.246 \mathrm{mmol})$ and diene $9(86 \mathrm{mg}, 0.246 \mathrm{mmol})$ were added to a flamedried Schlenk flask with stir bar, and were dissolved in the minimal amount of anhydrous toluene (1-2 mL). The headspace was purged with argon for 30 minutes, then heated to reflux overnight $\left(111^{\circ} \mathrm{C}\right)$. The solvent was concentrated in vacuo. $\mathrm{KO}^{t} \mathrm{Bu}(496 \mathrm{mg}, 4.42 \mathrm{mmol}$ ) and $20 \mathrm{~mL}$ THF were added to the flask, and the reaction was allowed to stir $1-3 \mathrm{~h}$ under ambient conditions. The blue reaction mixture was then poured over $\mathrm{NH}_{4} \mathrm{Cl}(\mathrm{aq})$ and extracted with EtOAc. The organic 
layer was dried with $\mathrm{MgSO}_{4}$, filtered and evaporated. Gravity column $\left(\mathrm{SiO}_{2}: \mathrm{CH}_{2} \mathrm{Cl}_{2}\right)$ or $\mathrm{FC}\left(\mathrm{SiO}_{2}\right.$; hexanes then $\left.\mathrm{CH}_{2} \mathrm{Cl}_{2}\right)$ yielded an orange solid 15 (53 mg, 30\% yield). Mp: $251-253{ }^{\circ} \mathrm{C} . \mathrm{R}_{\mathrm{f}}=0.88\left(\mathrm{CH}_{2} \mathrm{Cl}_{2}\right) .{ }^{1} \mathrm{H}$ NMR $\left(400 \mathrm{MHz}, \mathrm{CDCl}_{3}\right): \delta 13.13(\mathrm{~s}, 2 \mathrm{H})$, $7.72(\mathrm{~d}, 4 \mathrm{H}, J=6.9 \mathrm{~Hz}), 7.69(\mathrm{~s}, 2 \mathrm{H}), 7.52(\mathrm{t}, 4 \mathrm{H}, J=7.4 \mathrm{~Hz}), 7.49-7.41(\mathrm{~m}, 6 \mathrm{H})$, $7.20(\mathrm{dd}, 2 \mathrm{H}, J=5.4,3.0 \mathrm{~Hz}), 7.08(\mathrm{dd}, 2 \mathrm{H}, J=5.4,3.0 \mathrm{~Hz}), 7.05-6.99(\mathrm{~m}, 4 \mathrm{H})$, 6.07 (s, 2H), $4.31 \mathrm{ppm}(\mathrm{s}, 2 \mathrm{H}) .{ }^{13} \mathrm{C} \mathrm{NMR}\left(101 \mathrm{MHz}, \mathrm{CDCl}_{3}\right): \delta 180.2,153.3,150.6$, $147.6,146.2,144.2,144.0,135.7,134.6,128.9,128.6,127.5,126.8,125.8,125.7$, $124.5,124.4,121.2,119.7,111.2,89.0,55.6,47.6 \mathrm{ppm}$. UV/vis $\left(\mathrm{CH}_{2} \mathrm{Cl}_{2}\right): \lambda_{\max }(\varepsilon)=$ 280 (68245), 494 (13190), $529 \mathrm{~nm}\left(7575 \mathrm{M}^{-1} \mathrm{~cm}^{-1}\right)$. HR-DART-MS: $\mathrm{m} / z$ calcd for $\mathrm{C}_{50} \mathrm{H}_{29} \mathrm{O}_{5}^{-}:$709.2020; found: $709.2000[\mathrm{M}-\mathrm{H}]^{-}$.

\section{Compound 3}

In a flame-dried $25 \mathrm{~mL}$ Schlenk flask, compound 15 (22 mg, $0.031 \mathrm{mmol})$, was dissolved in 1:1 isopropyl alcohol- $\mathrm{CHCl}_{3}(0.5 \mathrm{~mL}$ each). Concentrated $\mathrm{HCl}(0.2 \mathrm{~mL})$ was added slowly to the solution under argon. The solution was heated to $80{ }^{\circ} \mathrm{C}$ for 4 hours. The product was washed with deionized water and extracted with $\mathrm{CH}_{2} \mathrm{Cl}_{2}$, then concentrated in vacuo. The product was washed with hexanes, then filtered and dried overnight under vacuum, affording 3 as an orange solid (16 mg, 75\% yield). Mp: $>350{ }^{\circ} \mathrm{C} . \mathrm{R}_{\mathrm{f}}=0.95\left(\mathrm{CH}_{2} \mathrm{Cl}_{2}\right) .{ }^{1} \mathrm{H}$ NMR $\left(500 \mathrm{MHz}, 1,1,2,2\right.$-tetrachloroethane- $\left.\mathrm{d}_{2}\right): \delta$ $13.10(\mathrm{~s}, 2 \mathrm{H}), 7.84(\mathrm{dd}, 2 \mathrm{H}, J=6.3,3.4 \mathrm{~Hz}), 7.64-7.59(\mathrm{~m}, 8 \mathrm{H}), 7.58-7.50(\mathrm{~m}$, 6H), $7.49(\mathrm{~s}, 2 \mathrm{H}), 7.32(\mathrm{dd}, 2 \mathrm{H}, J=6.3,3.4 \mathrm{~Hz}), 7.09(\mathrm{dd}, 4 \mathrm{H}, J=5.5,3.1 \mathrm{~Hz}), 6.11$ ppm (s, 2H). ${ }^{13} \mathrm{C}$ NMR (125 MHz, 1,1,2,2-tetrachloroethane-d $\left.\mathrm{d}_{2}\right): \delta 186.0,155.8$, $153.1,146.0,143.7,141.7,135.8,135.1,134.7,131.3,129.3,128.9,128.4,127.34$, $127.30,125.6,124.4,114.9,110.7,47.2 \mathrm{ppm} . \mathrm{UV} / \mathrm{vis}\left(\mathrm{CH}_{2} \mathrm{Cl}_{2}\right): \lambda_{\max }(\varepsilon)=301$ (26248), 373, (20280), 517 (6910), $604 \mathrm{~nm}\left(3745 \mathrm{M}^{-1} \mathrm{~cm}^{-1}\right)$. MALDI-TOF-MS: $\mathrm{m} / z$ 
calcd for $\mathrm{C}_{50} \mathrm{H}_{29} \mathrm{O}_{5}^{-}$: 692.20; found: 692.538 [M] $]^{+}$. HR-DART-MS: $m / z$ calcd for $\mathrm{C}_{50} \mathrm{H}_{29} \mathrm{O}_{4}^{+}$: 693.2060; found: $693.2050[\mathrm{M}+\mathrm{H}]^{+}$.

\section{Synthesis of $\mathrm{BF}_{2}$ complexes}

Naphthazarin derivative $(20 \mathrm{mg}$ ) was added to a flame-dried Schlenk flask with stirrer bar, and were dissolved in dry $\mathrm{CH}_{2} \mathrm{Cl}_{2}(5 \mathrm{~mL})$ and $\mathrm{BF}_{3}-\mathrm{OEt}_{2}(0.5 \mathrm{~mL})$. The headspace was purged with argon, then stirred at room temperature for $1 \mathrm{~h}$. The solvent was concentrated in vacuo. The product was washed with hexanes and dried overnight under vacuum, affording $\mathrm{BF}_{2}$ complexes.

\section{Compound 1a-BF 2}

1a (20 mg, $0.037 \mathrm{mmol})$ : $\mathbf{1 a - B F _ { 2 }}$, dark purple solid $(18 \mathrm{mg}, 77 \%$ yield $) . \mathrm{R}_{\mathrm{f}}=0.89$ $\left(\mathrm{CH}_{2} \mathrm{Cl}_{2}\right) .{ }^{1} \mathrm{H}$ NMR (300 MHz, $\left.\mathrm{CDCl}_{3}\right): \delta 7.49$ (br. dd, 8H, $J=5.4,3.2 \mathrm{~Hz}$ ), 7.09 (br. $\mathrm{dd}, 8 \mathrm{H}, J=5.4,3.2 \mathrm{~Hz}), 6.10 \mathrm{ppm}(\mathrm{s}, 4 \mathrm{H})$. HR-ESI-MS: $m / z$ calcd for $\mathrm{C}_{38} \mathrm{H}_{20} \mathrm{~B}_{2} \mathrm{~F}_{4} \mathrm{O}_{4}{ }^{-}$: 638.1518; found: $638.1503[\mathrm{M}]^{-}$.

\section{ASSOCIATED CONTENT}

\section{Supporting Information.}

${ }^{1} \mathrm{H}$ and ${ }^{13} \mathrm{C}$ NMR spectra of all new compounds, crystal structure data for compounds 6b, 7a, 8a, 10, 11, and 12, UV/vis and fluorescence characterization, and TD-DFT calculations can be found in the Supporting Information for this manuscript. This material is available free of charge via the Internet at http://pubs.acs.org.

\section{AUTHOR INFORMATION}

\section{Corresponding Author}

*E-mail: tswager@mit.edu

Notes

The authors declare no competing financial interest. 
$\S$ These two authors contributed equally to this work.

\section{ACKNOWLEDGMENTS}

This work was supported by the National Science Foundation through award DMR1410718, and Graduate Research Fellowships (Grant No. 122374 (G. D. G. and S. P. L.) Any opinion, findings, and conclusions or recommendations expressed in this material are those of the authors(s) and do not necessarily reflect the views of the National Science Foundation. This was also supported by an Early Postdoc Mobility fellowship from the Swiss National Science Foundation (SNF) (C. D.). The authors thank Dr. Peter Müller and Dr. Jonathan Becker for collecting and solving X-ray structure data and Dr. Tristan Reekie for reviewing the manuscript. 


\section{REFERENCES}

(1) Anthony, J. E. Chem. Rev. 2006, 106, 5028-5048.

(2) Anthony, J. E. Angew. Chem. Int. Ed. 2008, 47, 452-483.

(3) Mei, J.; Diao, Y.; Appleton, A. L.; Fang, L.; Bao, Z. J. Am. Chem. Soc. 2013, $135,6724-6746$.

(4) Kaur, I.; Jia, W.; Kopreski, R. P.; Selvarasah, S.; Dokmeci, R. M.; Pramanik, C.; McGruer, N. E.; Miller, G. P. J. Am. Chem. Soc. 2008, 130, 16274-16286.

(5) Laquindanum, J. G.; Katz, H. E.; Lovinger, A. J. J. Am. Chem. Soc. 1998, 120, 664-672.

(6) Engelhart, J. U.; Lindner, B. D.; Tverskoy, O.; Rominger, F.; Bunz, U. H. F. Chem. - Eur. J. 2013, 19, 15089-15092.

(7) Yang, S.; Shan, B.; Xu, X.; Miao, Q. Chem. - Eur. J. 2016, 22, 6637-6642.

(8) Appleton, A.; Barlow, S.; Marder, S.; Hardcastle, K.; Bunz, U. Synlett 2011, 22, 1983-1986.

(9) Wang, C.; Zhang, J.; Long, G.; Aratani, N.; Yamada, H.; Zhao, Y.; Zhang, Q. Angew. Chem. Int. Ed. 2015, 54, 6292-6296.

(10) Li, J.; Zhang, Q. Synlett 2013, 24, 686-696.

(11) Li, J.; Chen, S.; Wang, Z.; Zhang, Q. Chem. Rec. 2016, 16, 1518-1530.

(12) Gu, P.-Y.; Wang, Z.; Liu, G.; Yao, H.; Wang, Z.; Li, Y.; Zhu, J.; Li, S.; Zhang, Q. Chem. Mater. 2017, 29, 4172-84175.

(13) Li, J.; Zhang, Q. ACS Appl. Mater. Interfaces 2015, 7, 28049-28062.

(14) Helson, H. E.; Vollhardt, P. C.; Yang, Z.-Y. Angew. Chem. Int. Ed. 1985, 24, 114-115. 
(15) Schleifenbaum, A.; Feeder, N.; Vollhardt, K. P. C. Tetrahedron Lett. 2001, 42, 7329-7332.

(16) Parkhurst, R. R.; Swager, T. M. J. Am. Chem. Soc. 2012, 134, 15351-15356.

(17) Parkhurst, R. R.; Swager, T. M. Top. Curr. Chem. 2014, 350, 141-176.

(18) Biegger, P.; Schaffroth, M.; Patze, C.; Tverskoy, O.; Rominger, F.; Bunz, U. H. F. Chem. - Eur. J. 2015, 21, 7048-7052.

(19) Luppino, S.; Swager, T. Synlett 2016, 28, 323-326.

(20) Chen, Z.; Müller, P.; Swager, T. M. Org. Lett. 2006, 8, 273-276.

(21) Miao, Q.; Chi, X.; Xiao, S.; Zeis, R.; Lefenfeld, M.; Siegrist, T.; Steigerwald, M. L.; Nuckolls, C. J. Am. Chem. Soc. 2006, 128, 1340-1345.

(22) Fukutani, T.; Hirano, K.; Satoh, T.; Miura, M. J. Org. Chem. 2011, 76, $2867-$ 2874.

(23) Echavarren, A.; Prados, P.; Farina, F. Tetrahedron 1984, 40, 4561-4567.

(24) de Bie, J. F. M.; Peperzak, R. M.; Daenen, M. J.; Scheeren, H. W. Tetrahedron 1993, 49, 6463-6472.

(25) Kelly, T. R.; Gillard, J. W.; Goerner, R. N.; Lyding, J. M. J. Am. Chem. Soc. 1977, 99, 5513-5514.

(26) Fariña, F.; Vega, J. C. Tetrahedron Lett. 1972, 13, 1655-1658.

(27) Carreño, M. C.; Ruano, J. L. G.; Urbano, A. J. Org. Chem. 1996, 61, 61366138.

(28) Ono, K.; Hashizume, J.; Yamaguchi, H.; Tomura, M.; Nishida, J. I.; Yamashita, Y. Org. Lett. 2009, 11, 4326-4329.

(29) Ono, K.; Yamaguchi, H.; Taga, K.; Saito, K.; Nishida, J. L.; Yamashita, Y. Org. Lett. 2009, 11, 149-152. 
(30) Cao, J.; Zhu, X. Z.; Chen, C. F. J. Org. Chem. 2010, 75, 7420-7423.

(31) Amara, J. P.; Swager, T. M. Macromolecules 2004, 37, 3068-3070.

(32) Quinti, L.; Allen, N. S.; Edge, M.; Murphy, B. P.; Perotti, A. J. Photochem. Photobiol. A Chem. 2003, 155, 79-91.

(33) Quinti, L.; Allen, N. S.; Edge, M.; Murphy, B. P.; Perotti, A. J. Photochem. Photobiol. A Chem. 2003, 155, 93-106.

(34) Kaupp, G.; Griiter, H.-W.; Teufel, E. Chem. Ber. 1983, 116, 618-629.

(35) Huntsman, W.; Wristers, H. J. Am. Chem. Soc. 1963, 85, 3308-3309.

(36) Huntsman, W.; Wristers, H. J. Am. Chem. Soc. 1967, 89, 342-347.

(37) Blomquist, A. T.; Maitlis, P. M. Proc. Chem. Soc. 1961, 332.

(38) Hopf, H. Angew. Chem. Int. Ed. 1970, 9, 732-732.

(39) Toda, F.; Garratt, P. Chem. Rev. 1992, 92, 1685-1707.

(40) Sauer, J.; Sustmann, R. Angew. Chem. Int. Ed. 1980, 19, 779-807.

(41) Jin, Z.; Teo, Y. C.; Zulaybar, N. G.; Smith, M. D.; Xia, Y. J. Am. Chem. Soc. 2017, 139, 1806-1809.

(42) Frisch, M. J.; Trucks, G. W.; Schlegel, H. B.; Scuseria, G. E.; Robb, M. A.; Cheeseman, J. R.; Montgomery Jr., J. A.; Vreven, T.; Kudin, K. N.; Burant, J. C.; Millam, J. M.; Iyengar, S. S.; Tomasi, J.; Barone, V.; Mennuci, B.; Cossi, M.; Scalmani, G.; Rega, N.; Petersson, G. A.; Nakatsuji, H.; Hada, M.; Ehara, M.; Toyata, K.; Fukuda, R.; Hasegawa, J.; Ishida, M.; Nakajima, T.; Honda, Y.; Kitao, O.; Nakai, H.; Klene, M.; Li, X.; Knox, J. E.; Hratchian, H. P.; Cross, J. B.; Bakken, V.; Adamo, C.; Jaramillo, J.; Gomperts, R.; Stratmann, R. E.; Yazyev, O.; Austin, A. J.; Cammi, R.; Pomelli, C.; Ochterski, J. W.; Ayala, P. Y.; Morokuma, K.; Voth, G. A.; Salvador, P.; Dannenberg, J. J.; Zakrzewski, V. G.; Dapprich, S.; Daniels, A. D.; Strain, M. C.; Farkas, O.; Malick, D. K.; Rabuck, A. D.; Raghavachari, K.; Foresman, J. B.; Ortiz, J. V.; Cui, Q.; Baboul, A. G.; Clifford, S.; Cioslowski, J.; Stefanov, B. B.; Liu, G.; Liashenko, A.; Piskorz, P.; Komaromi, I.; Martin, R. L.; Fox, D. J.; Keith, T.; Al-Laham, M. A.; Peng, C. Y.; Nanayakkara, A.; Challacombe, M.; Gill, P. M. W.; Johnson, B.; Chen, W.; Wong, M. W.; Gonzalez, C.; Pople, J. A. Gaussian 
03, revision E.01.; Gaussian, Inc.: Wallingford CT, 2004.

(43) Gomez, M.; González, F. J.; González, I. J. Electroanal. Chem. 2005, 578, 193-202.

(44) Armendariz-Vidales, G.; Frontana, C. Org. Biomol. Chem. 2014, 12, 63936398.

(45) Kelly, T. R.; Ananthasubramanian, L.; Borah, K.; Gillard, J. W.; Goerner, R. N.; King, P. F.; Lyding, J. M.; Tsang, W.-G.; Vaya, J. Tetrahedron 1984, 40, 4569-4577.

(46) Anathasubramanian, L.; Kelly, T. R.; Vaya, J. p-Nitrocarbobenzoxy naphthazarin. US4472312 A, 1983.

(47) Barnett, E. D. B.; Way, N. F. G.; Watson, J. W. Ber. Dtsch. Chem. Ges. 1933, 66, 1876-1891.

(48) Fu, P. P.; Harvey, R. G. J. Org. Chem. 1977, 42, 2407-2410.

(49) Bouffard, Z.; Eaton, R. F.; Müller, P.; Swager, T. M. J. Org. Chem. 2007, 72, 10166-10180. 


1
2
3
4
5
6
7
8
9
10
11
12
13
14
15
16
17
18
19
20
21
22
23
24
25
26
27
28
29
30
31
32
33
34
35
36
37
38
39
40
41
42
43
44
45
46
47
48
49
50
51
52
53
54
55
56
57
58
60

TOC Graphic

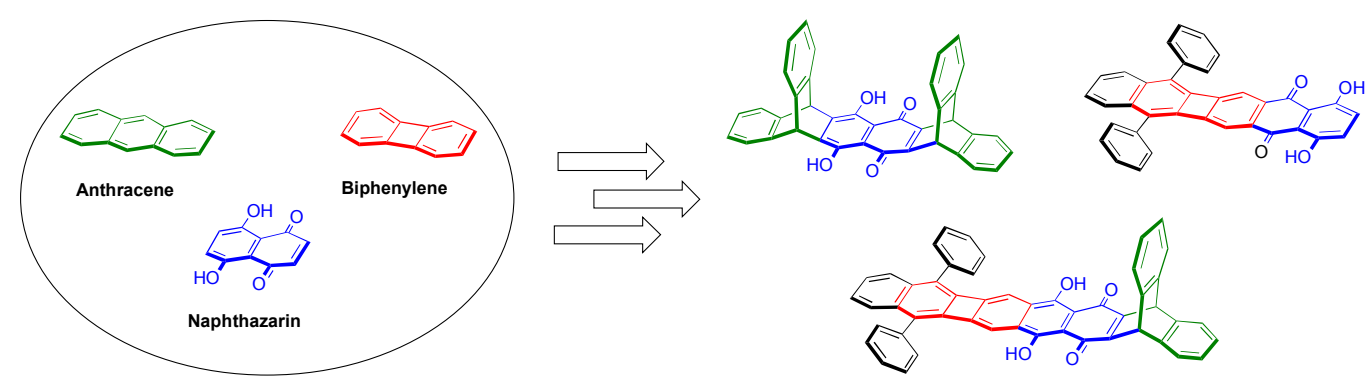

16

17

19

20

21

23

24

25

26

27

28

30

31

33

34

35
36

37

38

39

40

41

42

44

45

46

47

48

49

51

52

53

54

55

57

58

59

60 